\title{
Hydrological soil properties control tree regrowth after forest disturbance in the forest steppe of central Mongolia
}

\author{
Florian Schneider $^{1}$, Michael Klinge ${ }^{1}$, Jannik Brodthuhn ${ }^{1}$, Tino Peplau ${ }^{2}$, and Daniela Sauer ${ }^{1}$ \\ ${ }^{1}$ Department of Physical Geography, University of Göttingen, 37077 Göttingen, Germany \\ ${ }^{2}$ Intitute of Climate-Smart Agriculture, Johann-Heinrich von Thünen Institute, 38116 Braunschweig, Germany \\ Correspondence: Florian Schneider (florian.schneider@uni-goettingen.de)
}

Received: 24 August 2020 - Discussion started: 5 October 2020

Revised: 6 March 2021 - Accepted: 4 August 2021 - Published: 30 August 2021

\begin{abstract}
The central Mongolian forest steppe forms a transition between different ecozones and is as such particularly sensitive to environmental changes. It is commonly affected by disturbances such as logging and forest fires. Intensified drought events aggravate stress on the trees that are anyway at their drier limit in the forest steppe. Climate change increases evapotranspiration and reduces the distribution of discontinuous permafrost, which leads to drier soil conditions. The motivation for this study came about through our previous observation that forest stands show great differences with respect to their recovery after disturbance by fire or logging. Sometimes, no regrowth of trees takes place at all. As water availability is the main limiting factor of forest growth in this region, we hypothesised that differences in soil hydrology control the forest recovery pattern.

To test this hypothesis, we analysed soil properties under forests, predominantly consisting of Siberian larch (Larix sibirica Ledeb.), in the forest steppe of the northern Khangai Mountains, central Mongolia. We distinguished the following four vegetation categories: (1) near-natural forest (FOR), (2) steppe close to the forest (STE), (3) disturbed forest with regrowth of trees (DWIR), and (4) disturbed forest showing no regrowth of trees (DNOR). A total of 54 soil profiles were described in the field and sampled for soil chemical, physical, and hydrological analysis. We found a significant difference in soil texture between soils under DWIR and DNOR. Sand generally dominated the soil texture, but soils under DWIR had more silt and clay compared to soils under DNOR. Soil $p F$ curves showed that soils under DWIR had higher plant-available field capacity in their uppermost parts than soils under DNOR. In addition, hydraulic conductivity tended to be higher in the uppermost horizons of soils under DWIR compared to their counterparts under DNOR. Chemical properties of the soils under DWIR and DNOR showed no significant differences.

We conclude that the differences in post-disturbance tree regrowth are mainly caused by different soil hydrology. High plant-available field capacity is the key factor for forest recovery under semi-arid conditions. High hydraulic conductivity in the uppermost soil horizons can further support tree regrowth because it reduces the evaporation loss and the competition of larch saplings with grasses and herbs for water. Another important factor is human impact, particularly grazing livestock on cleared forest sites, which often keeps seedlings from growing and, thus, inhibits forest recovery. None of the disturbed sites (DWIR and DNOR) had permafrost. We, thus, conclude that permafrost is no major factor for the post-disturbance tree regrowth pattern, although it generally supports tree growth in the forest steppe by preventing meltwater from seasonal ice from seeping below the root zone, thus increasing the water supply in summer.
\end{abstract}




\section{Introduction}

The forest steppe in central Mongolia represents the transition between the Siberian taiga in the north and the Gobi Desert in the south, responding sensitively to climatic, ecological, and anthropogenic disturbances. Water availability is the key factor that determines where forest patches can exist within this landscape. Climate change is a major threat to the forest steppe due to aggravated drought stress (Allen et al., 2010). In Mongolia, intensified summer droughts became more frequent over the last century (Batima et al., 2005; Dashkhuu et al., 2015). Siberian larch (Larix sibirica Ledeb.), which is the dominant tree species in the Mongolian forest steppe, suffers due to these intensified droughts (Dulamsuren et al., 2010; Chenlemuge et al., 2015). Furthermore, summer droughts increase the risk of fires that disturb the vegetation structure in forests and reduce the size of the forest patches (Kharuk et al., 2008). This causes a negative effect on the forest microclimate, which in turn intensifies the sensitivity of the forest to drought stress (Khansaritoreh et al., 2017a). In addition to fire, the human impact also affects the structure of the forest stands. Logging and forest pasture reduce the forest size, open the forest stand, and hamper post-disturbance forest regrowth (Khishigjargal et al., 2013; Tsogtbaatar, 2013; Dulamsuren et al., 2014).

Meltwater from the active layer above permafrost patches increases the soil water availability and can, thus, support the survival of trees during drought events in summer (Sugimoto et al., 2002; Ishikawa et al., 2005; Churakova et al., 2016). Permafrost in Mongolia is discontinuous and especially occurs under large forests. However, climate change is currently reducing the area of permafrost in Mongolia (Sharkhuu and Sharkhuu, 2012). After forest disturbance by fire or logging, permafrost degrades and may only reconstitute under certain conditions (Klinge et al., 2021). The loss of this additional water source leads to the enhanced stress of trees during droughts.

Decreased water supply and increased drought stress raise the importance of soil properties in the Mongolian forest steppe even further. Soil water distribution in the landscape after a rainfall event is generally controlled by bedrock, sediment cover, slope morphology, and vegetation. In addition, plant-available field capacity and hydraulic conductivity of the soils influence the amount of water available at a site. Moreover, water repellency can reduce water infiltration, especially after fire events (DeBano, 2000; Doerr et al., 2000). Several studies have been conducted on soil distribution and soil properties in the Mongolian forest steppe (Opp and Hilbig, 2003; Maximovich, 2004; Lehmkuhl et al., 2011). Nandintsetseg and Shinoda (2011) modelled soil moisture conditions in Mongolia based on data from meteorological stations from 1986 until 2005. They obtained a gradient of increasing soil moisture from southwest to northeast during the summer. Haase (1963) studied soils in relation to altitudinal zones in the Khangai Mountains, including particle size distribution, chemical soil properties, and water content. He reported forest vegetation on soils with higher water content and predominant steppe vegetation on soils with lower water content. However, he focused mainly on general soil description and did not report any further details on soil-vegetation relationships. Krasnoshchekov $(2008,2010)$ described physical and chemical soil properties in the eastern Khubsugul region and the Khangai Mountains. Sympilova and Gyninova (2012) conducted similar research in the Selenga highlands. However, in both studies, only the soils were characterised, without linking them to the vegetation pattern. Sommer (2000) analysed soils of the forest steppe of the TurgenCharchiraa mountains in northwestern Mongolia. He focused on soil chemical aspects and did not find a clear relationship between forest distribution and soil properties. He concluded that forest distribution was climate controlled and disturbed by pastoral pressure and logging. Yet, he did not analyse soil hydrological properties.

During previous fieldwork in the Khangai Mountains, in the central Mongolian forest steppe, we observed that forest regrowth after disturbance does not proceed equally. The post-disturbance development of forest stands with apparently the same site conditions ranges from spontaneous dense regrowth to no regrowth at all. As the trees are at their drier limit in this sensitive landscape, we assumed that water availability is the main factor that controls forest regrowth after disturbance, whereas nutrient availability plays a less important role. Since both factors are related to soil properties, we established the following hypotheses:

1. Silty soil texture leads to high plant-available field capacity and is, thus, favourable for post-disturbance tree regrowth.

2. High hydraulic conductivity in the uppermost parts of the soils supports post-disturbance forest regrowth, as rapid water infiltration to some depth reduces evaporation and ground vegetation transpiration.

3. High nutrient stocks, for example after fire events, may support post-disturbance forest regrowth, unless nutrient stocks are well above the requirements of Siberian larch anyway. In this case, no effect is to be expected.

4. Permafrost may increase water availability for trees through the continuous water release at the melting front above the permafrost table over the summer season. As water above the permafrost table cannot infiltrate downwards, interflow may occur above the permafrost table. This process leads to increased water availability, especially in concave slope positions where interflow converges. Thus, permafrost may also support post-disturbance forest regrowth at sites with otherwise unfavourable soil hydrological conditions for forest regrowth. 


\section{Materials and methods}

\subsection{Study area}

The study area was located in the central Mongolian forest steppe, in the northern Khangai Mountains, near the town Tosontsengel (Fig. 1). The geological basement predominantly consists of Permian acidic plutonic and metamorphic sedimentary rock, with some occurrences of Carboniferous mafic rock (Academy of Sciences of Mongolia, 1990). Slope debris with mixed in aeolian sand and silt provides the parent material for the soils in the region. The widespread aeolian deposits originate from lacustrine sediments of big lakes that dried out during the glacial periods in the basin of Great Lakes, located between the Mongolian Altai Mountains and the Khangai Mountains (Grunert et al., 2000; Lehmkuhl and Haselein, 2000; Klinge and Lehmkuhl, 2013).

The climate is cold, semi-arid, and highly continental. In the town of Tosontsengel, in the northern part of the study area, the mean monthly temperatures range from $-31.7^{\circ} \mathrm{C}$ in January to $14.9^{\circ} \mathrm{C}$ in July (see Fig. S1 in the Supplement). Mean annual precipitation is $200-500 \mathrm{~mm}$. Rainfall concentrates in summer because of low-pressure cells that are blown in with the westerlies (Batima et al., 2005). The mean annual temperature of $-5.9^{\circ} \mathrm{C}$ supports discontinuous permafrost in the study area (Bonan and Shugart, 1989). Permafrost patches occur on forested slopes, where the canopy protects them from solar radiation, and the organic layer insulates them from high air temperatures in summer (Dashtseren et al., 2014). In summer, the forests benefit from an additional water supply by meltwater from the active layer above the permafrost (Zhang et al., 2011).

The vegetation of the study area is dominated by steppe. Only north-facing slopes and some valley positions are covered by forest, which predominately consist of Siberian larch (Hilbig, 1987; Tsogtbaatar, 2013). The understorey of these forests varies with respect to proportions of grasses, herbs, mosses, and shrubs (commonly including, e.g., Vaccinium vitis-idaea and Lonicera altaica). High evapotranspiration combined with low precipitation and relief-dependant differences in insolation control the vegetation pattern (Schlütz et al., 2008; Hais et al., 2016). The semi-arid conditions promote frequent forest fires in this region (Goldammer, 2002; Hessl et al., 2016). The last two severe fire events in the study area happened in 1996 and 2002.

A timber factory was established in the 1960s in Tosontsengel. Thus, logging strongly affected the forest stands in the study area. Since the 1990s, industrial logging has been abandoned, but illegal logging is still common (Lkhagvadorj et al., 2013). Moreover, pastoral pressure increased over the last few decades (Lkhagvadorj et al., 2013). Logging, followed by grazing, led to a reduction in the forested area, especially at its lower boundary and at the forest edges.

\subsection{Fieldwork}

The site selection within the study area was based on four categories of vegetation: near-natural forest (FOR), steppe close to forest (STE), disturbed forest with regrowth of trees (DWIR) and disturbed forest showing no regrowth of trees (DNOR; Figs. 1 and 2). In addition, we distinguished three categories of disturbance intensity. "Low intensity" included, e.g., logging of single trees. "Moderate" included logging of patches within a forest stand and fires that did not affect the whole forest stand. "Severe" included clear cutting and fires that destroyed the whole forest stand (Table A1; Appendix). To reduce the effects of factors that were not in the focus of this study, we kept geology, exposition (only northfacing slopes), inclination, and slope morphology as similar as possible. Elevation of the studied soil profiles ranged from 1850 to $2100 \mathrm{~m}$ a.s.l., which is well below the upper tree line of approx. $2500 \mathrm{~m}$ a.s.l. (Klinge et al., 2018). A total of 54 soil profiles were described according to the FAO Guidelines for Soil Description (Jahn et al., 2006) and classified according to the World Reference Base (WRB) for Soil Resources (IUSS Working Group WRB, 2015). The presence of permafrost was documented as well. The soil profiles were sampled horizon-wise, whereby thick horizons were subdivided for the sampling, such that the maximum thickness included in one sample did not exceed $30 \mathrm{~cm}$. We also carried out in situ measurements of saturated hydraulic conductivity, using a compact constant-head permeameter (Eijkelkamp; Amoozegar and Warrick, 1986; USDA, 2014). The measurements were done in five replicates. In addition, soil horizons with low rock fragment contents were sampled with 100 and $250 \mathrm{~cm}^{3}$ steel cylinders for laboratory measurements of $p F$ curves and hydraulic conductivity, respectively. Samples for $p F$ curves were taken during two field campaigns, whereas samples for hydraulic conductivity were taken only during one field campaign and, thus, not from all profiles that were sampled for $p F$ measurements. The in situ measurements of hydraulic conductivity provided additional data. Therefore, the sizes of the data sets for $p F$ curves and hydraulic conductivity differ.

\subsection{Laboratory analyses}

The soil samples were dried at $40^{\circ} \mathrm{C}$ and passed through a $2 \mathrm{~mm}$ sieve. Approximately $10 \mathrm{~g}$ of each sample was dried at $105^{\circ} \mathrm{C}$ to gravimetrically determine the remaining water contents for correcting all analytical data obtained from the samples dried at $40^{\circ} \mathrm{C}$. An aliquot of each sample was milled. Total $\mathrm{C}$ and $\mathrm{N}$ contents were analysed on the milled samples using a CHN analyser (LECO TruSpec). Carbonate contents were also analysed on the milled samples using the Scheibler method. Soil organic carbon (SOC) contents were calculated by subtracting soil inorganic $\mathrm{C}$ (obtained from carbonate analysis) from total $\mathrm{C}$. Soil $\mathrm{pH}$ was measured in $1 \mathrm{M} \mathrm{KCl}$ solution at a soil: solution ratio of $1: 5$. 


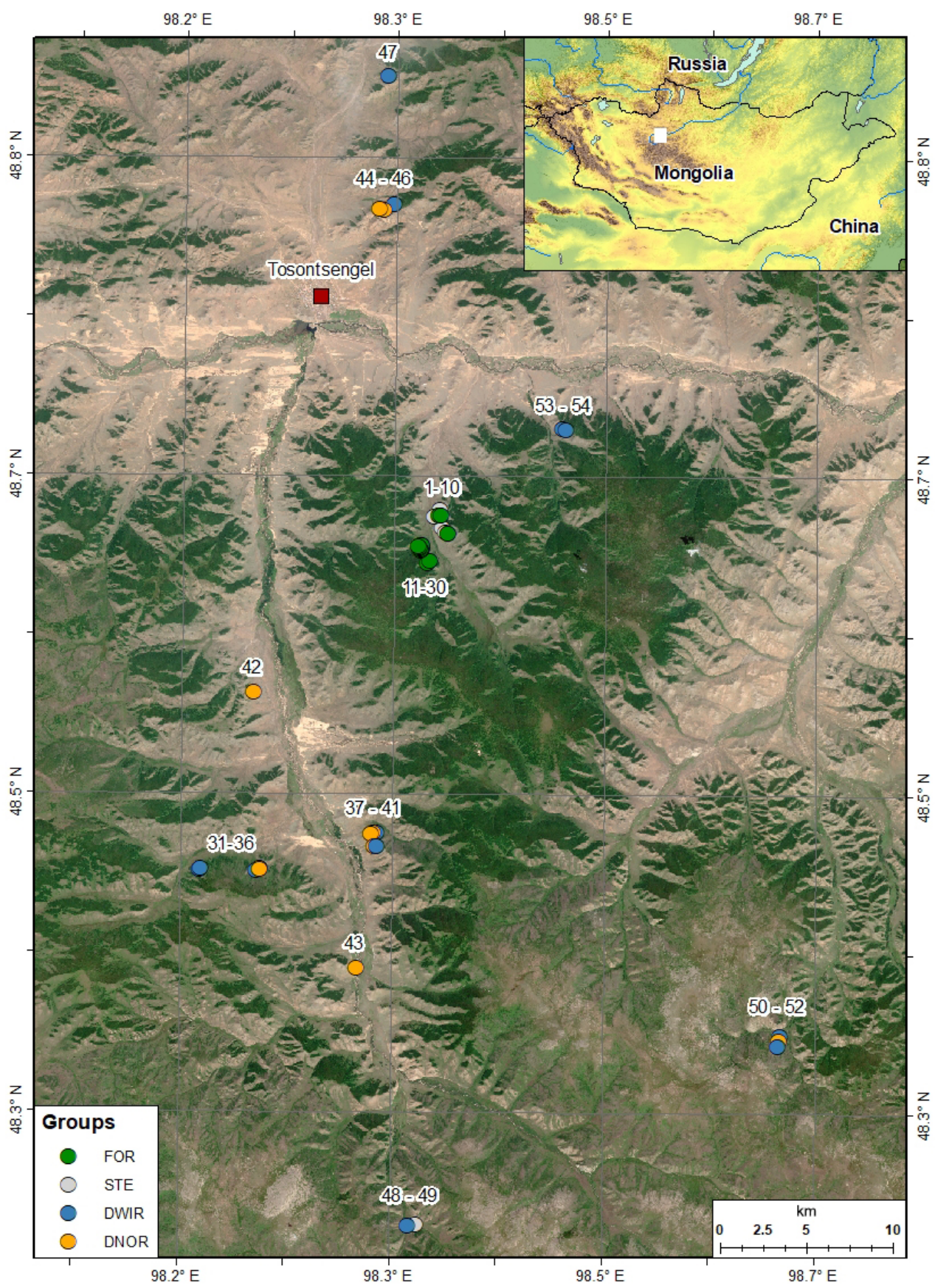

Figure 1. Sentinel image (31 July 2019) of the study area with soil profile positions. The colours indicate the four vegetation categories that were used for selecting the following soil profile locations: near-natural forest (FOR; green), steppe close to the forest (STE; grey), disturbed forest with regrowth of trees (DWIR; blue), and disturbed forest showing no regrowth of trees (DNOR; orange). The soil profiles are listed in Table 1 of the Appendix. The inset at the top right shows a physical map of Mongolia with the location of the study area (white square).

Exchangeable $\mathrm{Al}, \mathrm{Fe}, \mathrm{Mn}, \mathrm{Ca}, \mathrm{Mg}, \mathrm{K}$, and $\mathrm{Na}$ were extracted with $1 \mathrm{M}$ ammonium chloride solution and measured by use of an ICP-OES (inductively coupled plasma-optical emission spectrometer; Thermo Scientific). The effective cation exchange capacity (ECEC) was calculated as the sum of negative charges occupied by these exchangeable cations. Pre- treatments for particle size distribution analysis were as follows: soil organic matter was removed by $30 \% \mathrm{H}_{2} \mathrm{O}_{2}$, carbonates were dissolved, if necessary, by $10 \%$ hydrochloric acid, and micro-aggregates were dispersed by $0.4 \mathrm{M}$ sodium pyrophosphate. The three sand fractions were separated by sieving, and the silt and clay fractions were determined by 


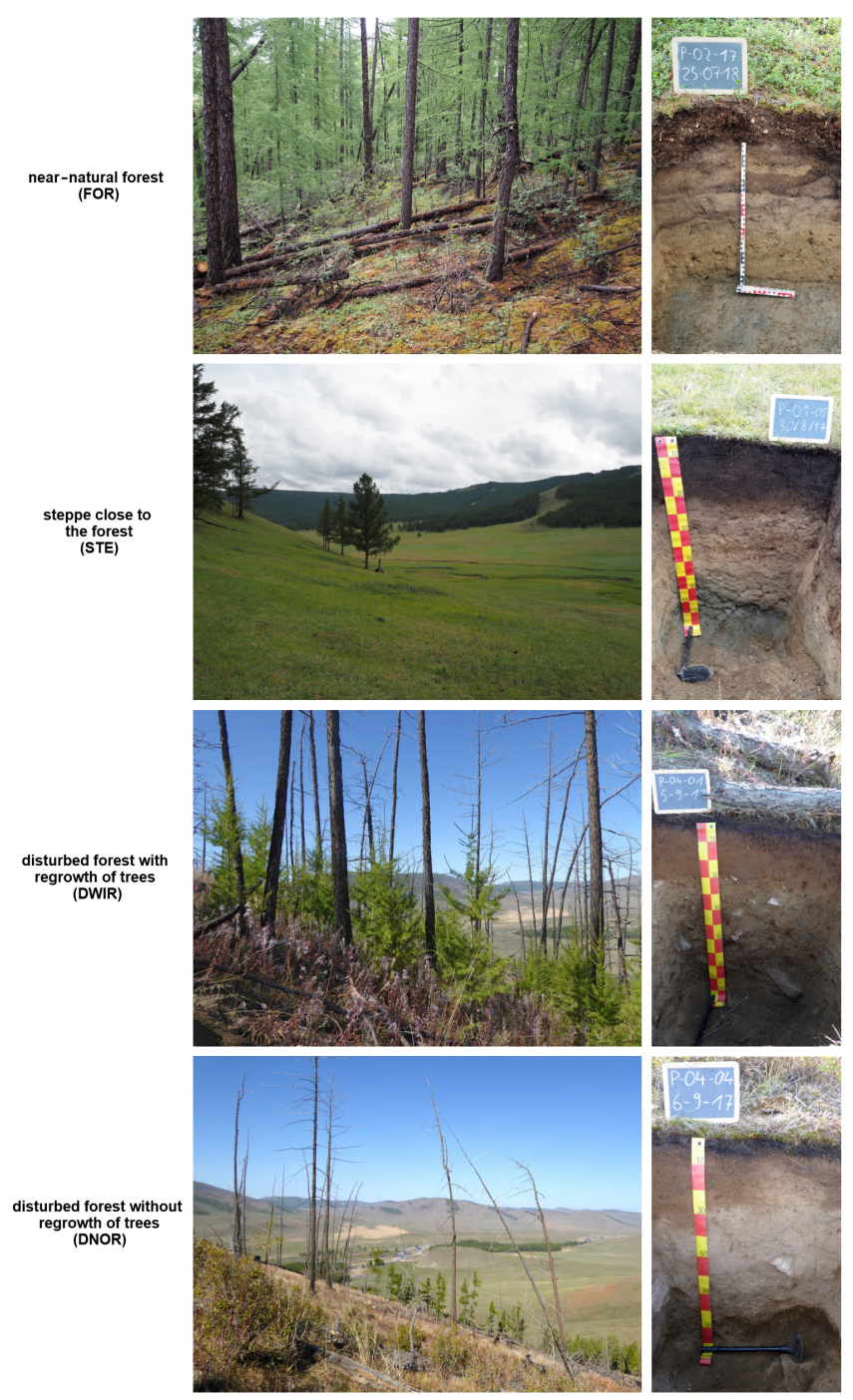

Figure 2. Typical soil profiles under the four vegetation categories.

use of a SediGraph (Micromeritics). Bulk density was estimated in the field (Jahn et al., 2006) and measured on undisturbed samples in the laboratory. All element concentrations in the fine earth were converted to element stocks per square metre considering rock fragment content and bulk density.

Hydraulic conductivity and $p F$ curves were determined on 41 of the soil profiles under FOR, DWIR, and DNOR. Hydraulic conductivity was measured in five replicates, using a permeability device with falling water head (self-constructed device based on the German norm DIN 19683-9). Soil $p F$ curves were determined in four to five replicates, using a pressure device (EcoTech). The cylinders with the samples were carefully water saturated and placed on ceramic plates in the pressure pots. Pressures corresponding to $p F 1.8,2.5$, and 4.2 were applied, and the weight of the samples at each $p F$ was determined. Water repellency was analysed on five replicates for each top soil sample (Doerr, 1998). The sam- ple was placed in a petri dish, and the surface was manually smoothened. The time was measured until a drop of distilled water, released from a pipette at $5 \mathrm{~cm}$ above the sample surface, infiltrated into the sample.

\subsection{Data processing and statistical analysis}

We described and sampled the soil profiles down to either the bedrock or permafrost, resulting in a maximum depth of $180 \mathrm{~cm}$. According to the literature, the roots of Siberian larch can reach this depth (Kapper, 1954; Albenskiy et al., 1956). Therefore, we included all soil horizons in the calculations of element stocks to evaluate the nutrient availability for larch trees at a site. To assess, in addition, the site conditions for tree seedlings without fully developed root system, we only used the properties of the uppermost $10 \mathrm{~cm}$ of the soils. For this purpose, we calculated the weighted means of the following variables for the uppermost $10 \mathrm{~cm}$ of the soils: content of rock fragments, bulk density, $\mathrm{H}+$ concentration $\left(\log \left(10^{-\mathrm{pH}}\right)\right)$, carbonate content, clay content, silt content, sand content, and ECEC (first group of variables). Element contents in the fine earth of each horizon were converted to element stocks per horizon (considering rock fragment content and bulk density) and were summed up over the uppermost $10 \mathrm{~cm}$ of the soils. This was done for exchangeable $\mathrm{Al}$, $\mathrm{Ca}, \mathrm{K}, \mathrm{Na}, \mathrm{Mg}, \mathrm{Mn}, \mathrm{Fe}, \mathrm{SOC}$, and total $\mathrm{N}$ (TN; second group of variables).

All statistical analyses were carried out with the $\mathrm{R}$ project for statistical computing (R Core Team, 2014). The share of each horizon in the uppermost $10 \mathrm{~cm}$ of the soil was used for the weighting, based on the formula $x 1$ (Eq. 1), for the first group of variables, and the formula $x 2$ (Eq. 2), for the second group of variables.

$$
\begin{aligned}
x 1= & \text { if }(\text { upper boundary }>10)\{\mathrm{NA}\} \\
& \text { else }\{\text { if }(\text { lower boundary }<=10) \\
& \{(\text { lower boundary-upper boundary }) / 10\} \\
& \text { else }\{(10-\text { upper boundary }) / 10\}\}, \\
x 2= & \text { if }(\text { upper boundary }>10)\{\mathrm{NA}\} \\
& \text { else }\{\text { if }(\text { lower boundary }<=10)\{1\} \\
& \text { else }\{((\text { lower boundary-upper boundary) } \\
& -(\text { lower }, \text { boundary }-10)) / \\
& \text { (lower boundary-upper boundary })\}\} .
\end{aligned}
$$

We conducted all statistical analyses (i) on the entire data set of each profile and (ii) on only the data of the uppermost $10 \mathrm{~cm}$ of each profile. All analyses and graphical representations were performed with the R packages "aqp", "ggplot2", and "ggpubr" (Beaudette et al., 2013; Wickham, 2016; Kassambara, 2019). Principle component analyses (PCAs) were calculated and graphically depicted with the R packages "FactoMineR" and "factoextra" (Lê et al., 2008; Kassambara and Mundt, 2019). The PCAs were used to identify relations 
between the variables and the samples. The PCA of the uppermost $10 \mathrm{~cm}$ of the soils also included inclination, exposition, and elevation. Linear regression models were used to compare the data obtained for soils under DWIR and DNOR. The results, including $95 \%$ confidence intervals, described the differences between the soils under DWIR and DNOR.

We did not subject measured plant-available field capacity $\left(\mathrm{FC}_{\mathrm{pa}}\right)$ and hydraulic conductivity to statistical analysis because of their unequal representation of the vegetation groups. Although we tried to sample as many profiles as possible, high rock fragment contents prevented equal sampling of soils under the different vegetation groups and resulted in a small number of samples. Thus, we only present the measured data in a site-wise comparison to prevent any bias.

In addition, we applied a pedotransfer function to estimate $\mathrm{FC}_{\mathrm{pa}}$ for all soil horizons, based on other measured soil parameters that were available for all samples. We tested several transfer functions from the literature and chose the function established by Gupta and Larson (1979) because it matched best with our measured $p F$ data, is based on a large data set (43 soils and a test run on 61 soils), and included a wide range of different soils ( $0 \%-65 \%$ clay content; $1 \%-$ $72 \%$ silt content; $5 \%-98 \%$ sand content; $0.74-1.74 \mathrm{~g} \mathrm{~cm}^{3}$ bulk density; see Table $\mathrm{S} 1$ ). We calculated the plant-available field capacity $\left(\mathrm{FC}_{\mathrm{pa}, \mathrm{cal}}\right)$ as follows:

$$
\begin{aligned}
\mathrm{FC}_{\mathrm{pa}, \mathrm{cal}}(\mathrm{vol} \%) & =(0.005678 \cdot \operatorname{sand}(\%) \\
& +0.009228 \cdot \operatorname{silt}(\%) \\
& +0.009135 \cdot \operatorname{clay}(\%) \\
& +0.006103 \cdot C_{\mathrm{org}}(\%) \\
& \left.-0.2696 \cdot \operatorname{bulk} \text { density }\left(\mathrm{g} \mathrm{cm}^{-3}\right)\right) \\
& -(-0.000059 \cdot \operatorname{sand}(\%) \\
& +0.001142 \cdot \operatorname{silt}(\%) \\
& +0.005766 \cdot \operatorname{clay}(\%) \\
& +0.002228 \cdot C_{\mathrm{org}}(\%)+0.02671 \\
& \left.\cdot \text { bulk density }\left(\mathrm{g} \mathrm{cm}^{3}\right)\right) \cdot 100 .
\end{aligned}
$$

The results were multiplied by fine earth content (volumetric fine earth content; hereafter vol \%), thus assuming that rock fragments did not contribute to $\mathrm{FC}_{\mathrm{pa}}$. We deleted three values from the resulting $\mathrm{FC}_{\mathrm{pa} \text {,cal }}$ data set because they exceeded a $\mathrm{FC}_{\mathrm{pa}, \mathrm{cal}}$ of $40 \mathrm{vol} \%$, which we considered unrealistic.

\section{Results}

\subsection{Field observations}

The bedrock in the study area predominantly consisted of granite, with some minor occurrences of gneiss. Thick aeolian sand sheets locally covered the lower slopes and valley bottoms along west-east running valleys (Fig. 1). Thus, carbonates that were observed in some of the soils were supposed to originate from aeolian deposits.

The parent materials of the soils on the slopes generally consisted of a vertical succession of two to three sediment layers. The lowermost one was typically a solifluction layer, characterised by a high content of rock fragments with sizes ranging from fine gravel to angular stones. This layer was usually overlain by another slope deposit, consisting of a mixture of weathering products of the bedrock, and aeolian sand and silt. This slope deposit showed lower rock fragment contents than the underlying one but similar rock fragment sizes. The proportions of sand and silt in the upper slope deposit varied both within a profile and between the profiles. In places, a Holocene colluvial deposit with varying thickness covered the slope deposits described above. Our profiles 4, 5 , and 38 predominantly consisted of Holocene colluvium, whereas most of the other profiles included either no or only a thin Holocene colluvial deposit. The Holocene colluvial deposits had very low contents of rock fragments that typically consisted of fine to medium gravel. At three sites, only a thin sediment layer covered the bedrock (profiles 3, 47, and 52). As an exception, the parent material at one of the forest sites (profiles 1, 2, 7, 8, and 9) consisted of a slope deposit with extremely high proportions of aeolian sand.

Phaeozems and Cambisols were the most common soils under the near-natural forests (FOR) and disturbed areas (DWIR, DNOR). In addition, Cryosols occurred above permafrost patches. Soils under steppe (STE) included Phaeozems, Chernozems, and Kastanozems. The soil structure of the A horizons was generally granular, the B horizons had a subangular or angular blocky structure, and the $\mathrm{C}$ horizons had a single grain, massive, or rock structure. Rock fragments in several $\mathrm{C}$ horizons showed manganese or carbonate pendants (Table A1; Appendix). Bioturbation by rodents was observed in the soils at one forest site (profiles 1 , $2,7,8$, and 9), whereas cryoturbation was not found at any of the investigated sites, most likely because of insufficient moisture. Charcoal was present in most of the topsoils.

Human impact affected most of the sites, except for the near-natural forest sites (FOR) that showed either no or only minor disturbance, such as the cutting of single trees. Disturbance in DWIR and DNOR varied between moderate and severe. Most of the sites were impacted by both fire and logging; yet, some profiles were only affected by one type of disturbance (Table A1; Appendix).

Permafrost was only encountered in soil profiles under near-natural forest (FOR). The depth of the permafrost table 
varied between 60 and $100 \mathrm{~cm}$ in soils on slope debris under closed forests and between 140 and $180 \mathrm{~cm}$ in soils on sandy deposits under open forests (Table A1; Appendix). In soils under STE, DWIR, and DNOR, no permafrost was present above the bedrock that was typically encountered between 80 and $110 \mathrm{~cm}$ soil depth.

\subsection{Chemical and physical soil properties}

Comparison of the entire soil profiles (down to either the bedrock or permafrost) showed that soils under STE had significantly higher contents of carbonates and exchangeable $\mathrm{Ca}$ than soils under all other vegetation categories (Fig. 3), whereas soils under FOR had significantly higher contents of exchangeable Fe compared to soils under all other vegetation categories. There were no statistically significant differences between soils under DWIR and DNOR with respect to rock fragment contents, SOC and TN stocks, $\mathrm{pH}$, contents of exchangeable $\mathrm{Mg}, \mathrm{K}, \mathrm{Na}, \mathrm{Al}, \mathrm{Mn}$, and ECEC. However, soils under DWIR and DNOR differed significantly in their particle size distribution. Soils under DWIR had higher silt and clay contents, whereas soils under DNOR had higher sand contents. Soils under FOR had similar silt contents to soils under DWIR, whereas soils under STE had similar sand contents to soils under DNOR. Bulk density of soils under FOR and DWIR was lower than that of soils under DNOR. Yet, there was only a significant difference in bulk density between soils under FOR and DNOR but not between soils under DWIR and DNOR.

Comparison of only the uppermost $10 \mathrm{~cm}$ of each soil profile (for evaluating the soil conditions for tree seedlings) suggested that soils under DWIR had larger stocks of exchangeable $\mathrm{Mg}$ and $\mathrm{K}, \mathrm{SOC}$, and TN than soils under DNOR; however, these were without significant differences (Fig. 4). The other chemical soil properties showed no differences between soils under DWIR and DNOR. In contrast, the particle size distribution again showed a significant difference between soils under DWIR and DNOR. Soils under STE had the highest sand contents, followed by soils under DNOR. Soils under DWIR had the highest clay and silt contents, followed by soils under FOR. Bulk densities and rock fragment contents of the soils of the four vegetation categories were similar.

In the principle component analysis (PCA) of the data for the entire soil profiles, the first two factors explained $56.3 \%$ of the total variance (Fig. 5a). The variables of sand content, rock fragment content, and bulk density, on the one hand, made up one axis together with clay and silt contents, on the other hand. Most of the data scattered around this axis, regardless of the vegetation category. Exchangeable Al and $\mathrm{Fe}$, on the one hand, made up a second axis together with $\mathrm{pH}$, carbonate content, and exchangeable $\mathrm{Ca}$ and $\mathrm{Na}$, on the other hand. Exchangeable $\mathrm{Al}$ and Fe did not contribute much to the PCA, on the one hand, yet the soils under FOR clustered around them. On the other hand, some soils un- der STE, DNOR, and FOR clustered around $\mathrm{pH}$, carbonate content, and exchangeable $\mathrm{Ca}$ and $\mathrm{Na}$. In addition, another cluster around SOC and TN stocks, and exchangeable $\mathrm{Mg}$, $\mathrm{K}$, and $\mathrm{Mn}$, occurred close to the axis of clay and silt contents. Mainly soils under DWIR, but also some soils under STE, fell into this cluster.

In the PCA of the data for the uppermost $10 \mathrm{~cm}$ of the soil profiles, the first two factors explained $54.5 \%$ of the total variance (Fig. 5b). Sand content and bulk density on one hand, made up one axis together with silt content, on the other hand. Rock fragment content and exchangeable Fe and $\mathrm{Al}$, on one hand, made up a second axis together with $\mathrm{pH}$, on the other hand. In addition, a cluster of clay content, SOC and TN stocks, ECEC, and exchangeable $\mathrm{Mg}, \mathrm{K}$, and $\mathrm{Mn}$ occurred. The factor elevation also fell into this cluster but with a minor contribution. The contributions of inclination, exposition, carbonate content, and exchangeable $\mathrm{Na}$ were negligible. In general, the data for the uppermost $10 \mathrm{~cm}$ of the soils under the four vegetation categories (lower PCA) plotted more separately from each other than those for the entire soil profiles (upper PCA). The arithmetic means and $95 \%$ confidence intervals of the data for the uppermost $10 \mathrm{~cm}$ of the soils under the four vegetation categories (smaller dots and shaded ellipses) confirmed the differences and clear separation. Soils under FOR plotted around the axes of sand and exchangeable Fe and Al. Soils under STE concentrated around sand and bulk density, thereby slightly shifting to the side of exchangeable $\mathrm{Ca}, \mathrm{Mg}, \mathrm{K}$, and SOC and TN stocks. Soils under DWIR plotted closer to silt than to sand and mostly fell into the cluster of ECEC, exchangeable $\mathrm{Mg}, \mathrm{K}$, and SOC and TN stocks. Soils under DNOR plotted between those under STE and DWIR. The confidence interval of the soils under FOR was clearly separated from all other confidence intervals. That of the soils under DWIR was also separated and showed only a minor overlap with the one of soils under DNOR. The confidence intervals of the soils under STE and DNOR showed a considerable overlap.

Based on the data presented in Figs. 3-5, we chose the most relevant variables for direct comparison of the soil properties under DWIR and DNOR, using multiple linear regression models (Fig. 6). We found a significant difference in particle size distribution, both for the data of the entire soil profiles (Fig. 6a) and for the uppermost $10 \mathrm{~cm}$ of the soil profiles (Fig. 6b). Soils under DNOR clearly had more sand and less silt and clay than soils under DWIR. The soils did not exhibit significant differences with respect to any other soil properties. All confidence intervals overlapped with the zero line, and all $p$ values were $>0.05$. The only relevant observation was that the uppermost $10 \mathrm{~cm}$ of the soil profiles under DNOR tended to have smaller stocks of SOC and exchangeable $K$ compared to those under DWIR; however, these were without significant differences. 

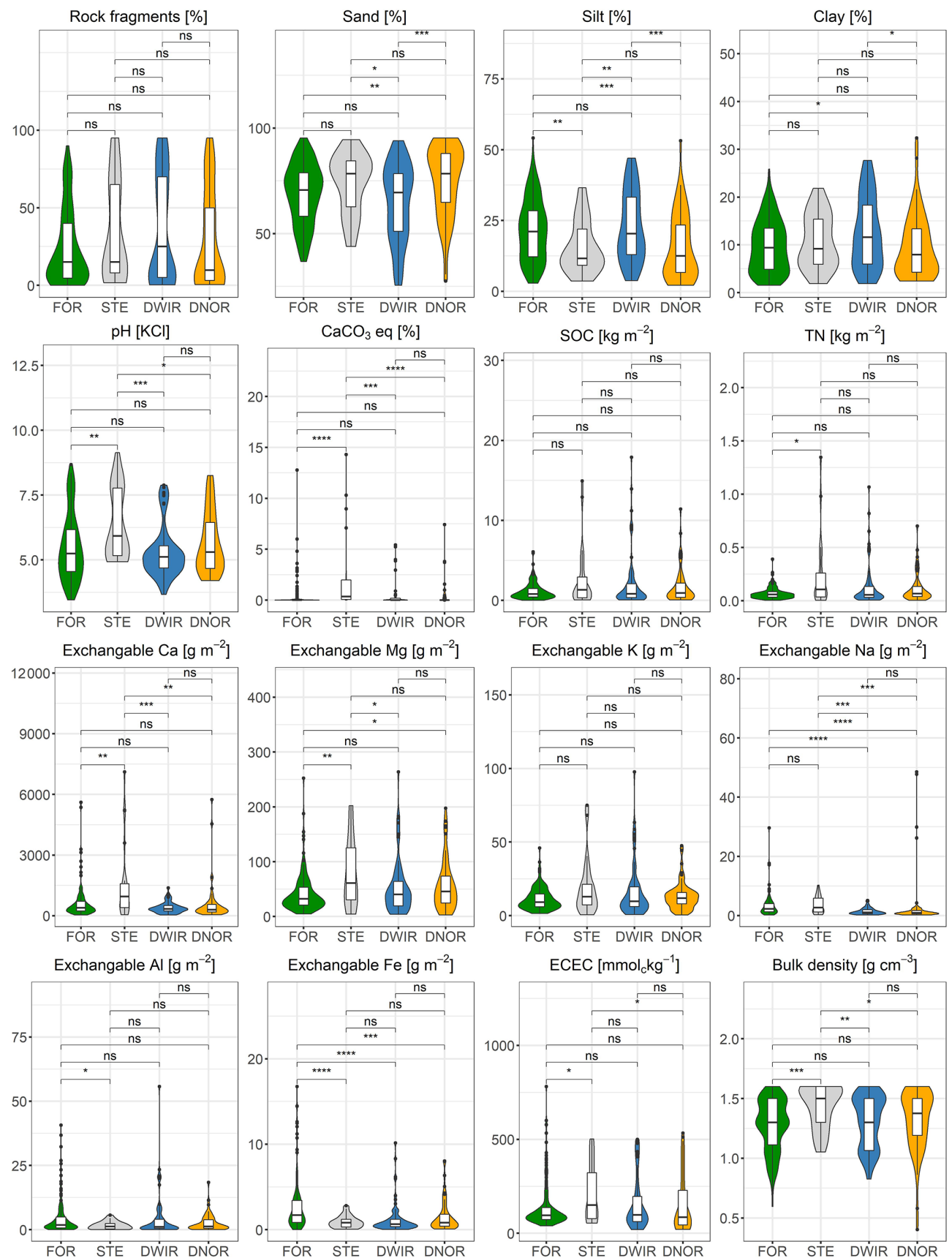

Figure 3. Properties of the entire soil profiles (down to either the bedrock or permafrost) under the following four vegetation categories $(n=305)$ : near-natural forest (FOR; green), steppe close to the forest (STE; grey), disturbed forest with regrowth of trees (DWIR; blue), and disturbed forest showing no regrowth of trees (DNOR; orange). $P$ values indicated above the plots were calculated for differences between the arithmetic means (ns $-p>0.05 ;^{*}-p \leq 0.05$; $^{* *}-p \leq 0.01$; $^{* *}-p \leq 0.001$; $^{* * * *}-p \leq 0.0001$ ). Horizontal bars are medians, boxes are first and third quartiles, points are outliers, and violins are data distributions.

\subsection{Hydrological soil properties}

In general, all soils had high hydraulic conductivities due to their predominantly sandy texture. A site-wise comparison between soils under DWIR and DNOR showed that soils under DWIR tended to have higher hydraulic conductivities in their uppermost horizons (Fig. 7c). For example, the hydraulic conductivities of soil profiles 31 and 32 (DNOR) at site 1 were below $1.5 \times 10^{-3} \mathrm{~cm} \mathrm{~s}^{-1}$, whereas those of profiles 33-36 (DWIR) ranged between 1.5 and $3 \times 10^{-3} \mathrm{~cm} \mathrm{~s}^{-1}$. Profiles 38 and 40 (DNOR) at site 2 showed hydraulic conductivities between $2.5 \times 10^{-3}$ and $3.5 \times 10^{-3} \mathrm{~cm} \mathrm{~s}^{-1}$ in their 

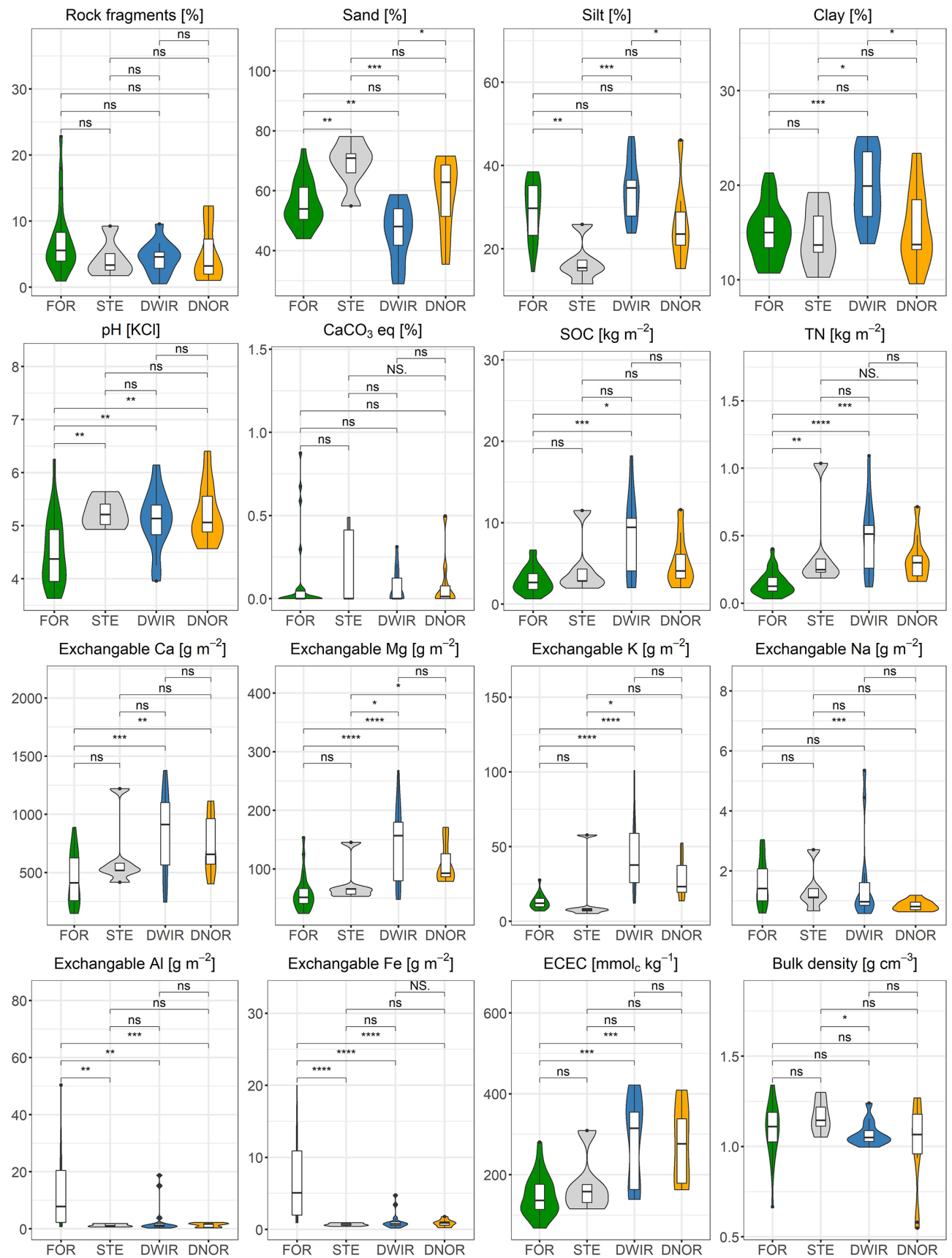

Figure 4. Properties of the uppermost $10 \mathrm{~cm}$ of the soil profiles under the following four vegetation categories $(n=54)$ : near-natural forest (FOR; green), steppe close to the forest (STE; grey), disturbed forest with regrowth of trees (DWIR; blue) and disturbed forest showing no regrowth of trees (DNOR; orange). $P$ values indicated above the plots were calculated for differences between the arithmetic means (NS. $-p=1$; ns $-p>0.05 ;^{*}-p \leq 0.05$; $^{* *}-p \leq 0.01$; $^{* *}-p \leq 0.001$; $^{* * *}-p \leq 0.0001$ ). Horizontal bars are medians, boxes are first and third quartiles, points are outliers, and violins are data distributions.

uppermost horizons, while the hydraulic conductivities of profiles 37 and 41 (DWIR) exceeded $5 \times 10^{-3} \mathrm{~cm} \mathrm{~s}^{-1}$. Soils under FOR showed similar hydraulic conductivities, with a maximum of $3.5 \times 10^{-3} \mathrm{~cm} \mathrm{~s}^{-1}$ (Fig. 7a). Soils under FOR had lower plant-available field capacities $\left(\mathrm{FC}_{\mathrm{pa}}\right)$ than soils under DWIR and DNOR (Fig. 7). Except for one subsoil horizon, $\mathrm{FC}_{\mathrm{pa}}$ ranged from $12 \mathrm{vol} \%$ to $22 \mathrm{vol} \%$ in soils under FOR and from 12 vol \% to 33 vol $\%$ in soils under DWIR and DNOR. The differences between soils under DWIR and DNOR became clearer in a site-wise comparison. For example, $\mathrm{FC}_{\mathrm{pa}}$ of profiles 39 and 40 (DNOR) at site 2 ranged between $12 \mathrm{vol} \%$ and $17 \mathrm{vol} \%$, whereas profile 37 (DWIR) had 

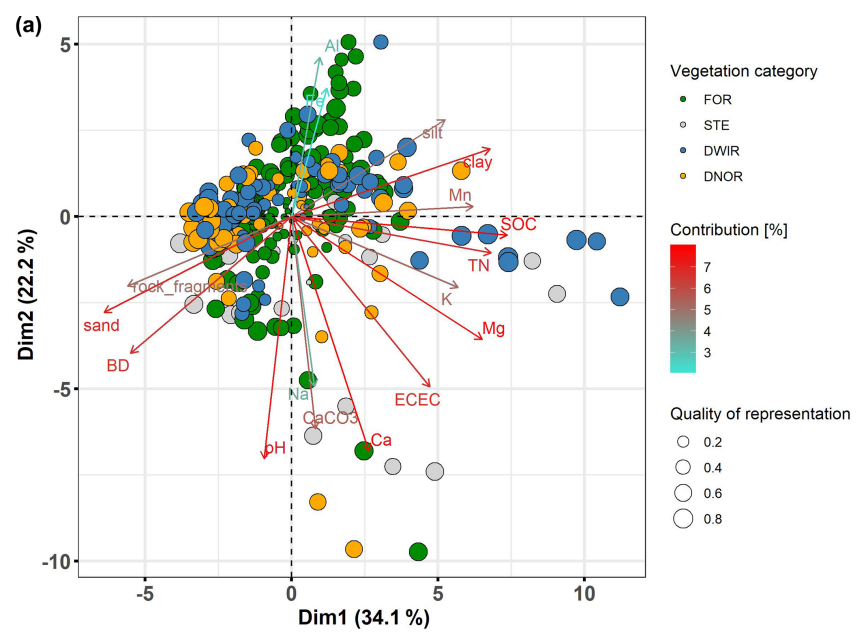

(b)

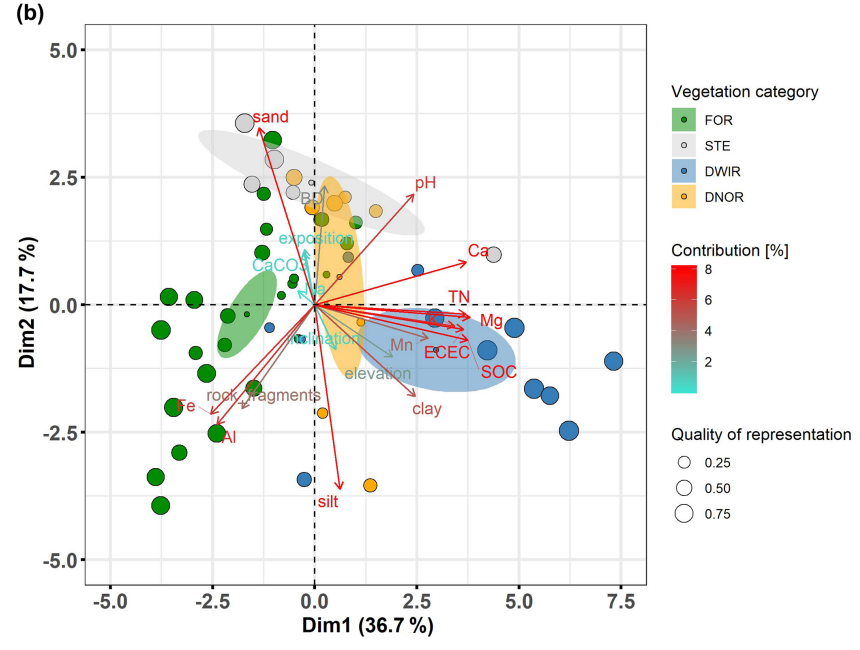

Figure 5. (a) PCA of the properties of the entire soil profiles under the following four vegetation categories $(n=303)$ : near-natural forest (FOR; green), steppe close to the forest (STE; grey), disturbed forest with regrowth of trees (DWIR; blue), and disturbed forest showing no regrowth of trees (DNOR, orange). (b) PCA of the properties of the uppermost $10 \mathrm{~cm}$ of the soil profiles under the four vegetation categories $(n=52)$. In addition, inclination, exposition, and elevation were included in the second PCA. Arithmetic means and $95 \%$ confidence intervals of the data for soils under each vegetation category are represented by a smaller circle and a shaded ellipse, respectively. SOC is soil organic carbon, TN is total nitrogen, ECEC is effective cation exchange capacity, BD is bulk density, and $\mathrm{Ca}$, $\mathrm{Mg}, \mathrm{K}, \mathrm{Na}, \mathrm{Al}, \mathrm{Fe}$, and $\mathrm{Mn}$ are exchangeable cations.

$\mathrm{FC}_{\mathrm{pa}}$ between $17 \mathrm{vol} \%$ and $26 \mathrm{vol} \%$. However, the limited number of samples analysed for $\mathrm{FC}_{\mathrm{pa}}$ did not allow for a final statement on differences between the sites with respect to $\mathrm{FC}_{\mathrm{pa}}$.

Plant-available field capacity calculated by pedotransfer functions from the literature $\left(\mathrm{FC}_{\mathrm{pa}, \mathrm{cal}}\right)$ and measured plantavailable field capacity $\left(\mathrm{FC}_{\mathrm{pa}}\right)$ did not match well, and the highest obtained $R^{2}$ was only 0.195 (see the Supplement; Table S1). We chose the pedotransfer function of Gupta and

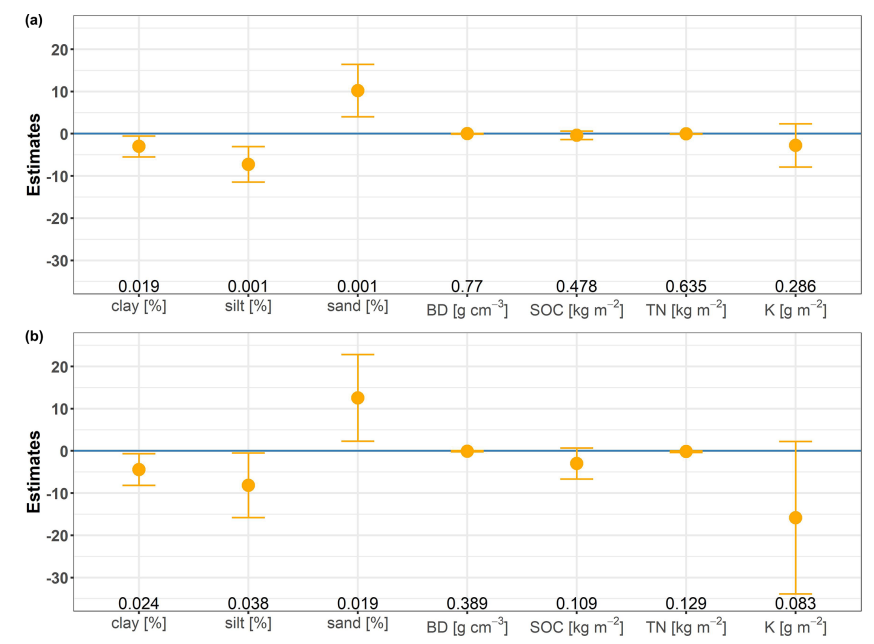

Figure 6. (a) Estimates and $95 \%$ confidence intervals of linear regression models, comparing entire soil profiles under disturbed forest showing no regrowth of trees (DNOR; orange) to those under disturbed forest with regrowth of trees (DWIR; blue; $n=305$ ). $P$ values indicated below the plots were calculated for the differences between the estimates for soils under DNOR and DWIR. Data for exchangeable $\mathrm{Mg}$ were left out for better readability (estimate is +4.5 ; confidence intervals are $+21.2 /-12.2 ; p=0.596$ ). (b) Estimates and $95 \%$ confidence intervals of linear regression models, comparing the uppermost $10 \mathrm{~cm}$ of the soil profiles under DNOR (orange) to those under DWIR (blue; $n=54$ ). $P$ values indicated below the plots were calculated for the differences between the estimates for soils under DNOR and DWIR. Data for exchangeable Mg were left out for better readability (estimate is -32.2 ; confidence intervals are $+16.5 /-80.9 ; p=0.184$ ). BD is bulk density, SOC is soil organic carbon, TN is total nitrogen, and $K$ is exchangeable potassium.

Larson (1979) because of the wide range of soils used in their data set, making it widely applicable. We assume that the mismatch with our measured data was due to the disturbance of the samples during the transport from Mongolia to Germany and due to high rock fragment contents in many of our samples, which created several problems. For instance, there was a risk that rock fragments might have been hit and slightly moved by the cylinders when these were hammered into the soil, and that moving the rock fragments, in turn, pushed the finer particles, thus slightly altering the pore size distribution. The contribution of rock fragments to $\mathrm{FC}_{\mathrm{pa}}$ was neglected, and there was uncertainty in the calculation of rock fragment content (vol \%), based on soil bulk density and an assumed rock density of $2.65 \mathrm{~g} \mathrm{~cm}^{3}$. $\mathrm{FC}_{\mathrm{pa} \text {,cal }}$ (vol \%) of each horizon was transformed into plant-available water volume at field capacity $\left(\mathrm{PAWV}_{\mathrm{FC}}\right)$ per square metre in the whole soil profile (Fig. 8a) and only in the uppermost $10 \mathrm{~cm}$ of the soils (Fig. 8b). Thereby, we assumed that PAWV $\mathrm{FC}_{\mathrm{FC}}$ stored in the whole profile is the relevant factor for mature trees, whereas $\mathrm{PAWV}_{\mathrm{FC}}$ stored in the uppermost $10 \mathrm{~cm}$ of 
(a)

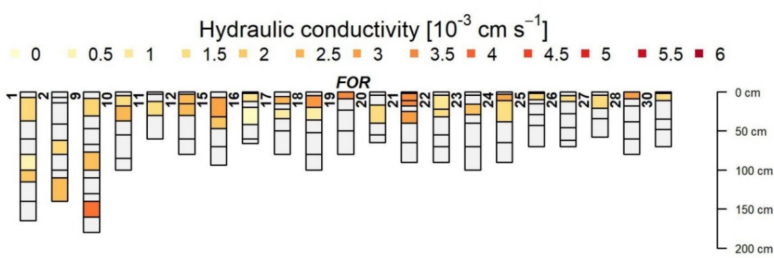

(b)

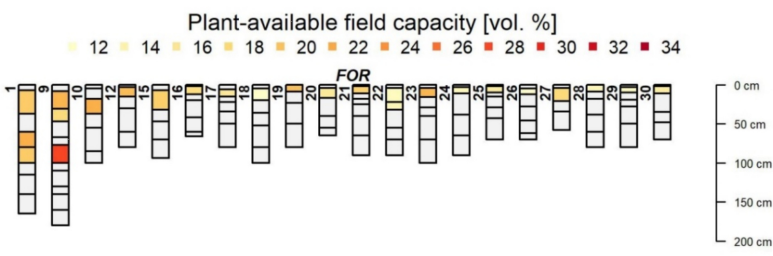

(c)

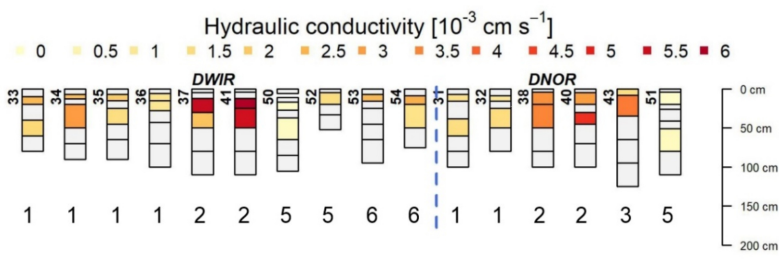

(d)

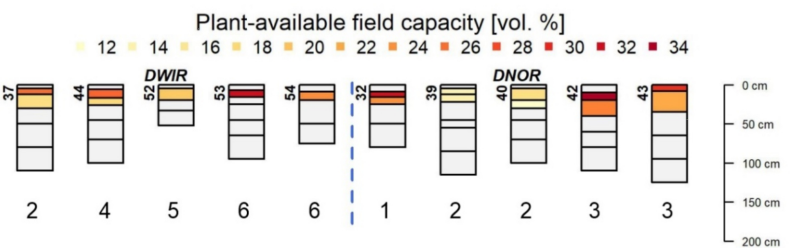

Figure 7. Hydraulic conductivities (a) and plant-available field capacities (b) of soils under near-natural forest (FOR) and hydraulic conductivities (c) and plant-available field capacities (d) of soils under disturbed forest with regrowth of trees (DWIR; left) and under disturbed forest showing no regrowth of trees (DNOR; right). Soil horizons in light grey were not subjected to these measurements. The same numbers under the profiles in panels (c) and (d) indicate that the profiles were located at the same site.

the soils is crucial for the reestablishment of seedlings after forest disturbance.

There were no significant differences in $\mathrm{PAWV}_{\mathrm{FC}}$ for the whole soil profiles among the four vegetation categories (Fig. 8a). In contrast, PAWV $\mathrm{FC}_{\mathrm{FC}}$ in the uppermost $10 \mathrm{~cm}$ was significantly higher in soils under DWIR compared to soils under all other vegetation categories (Fig. 8b). Soils under FOR, STE, and DNOR showed no significant difference in PAWV $_{\mathrm{FC}}$ in their uppermost $10 \mathrm{~cm}$. Soils under FOR exhibited a very wide range of PAWV $\mathrm{FC}_{\mathrm{FC}}$ in their uppermost $10 \mathrm{~cm}$.

Water repellency of topsoils under different vegetation categories did not show any differences (Fig. A2; Appendix). Topsoil samples from all vegetation categories included samples on which the water drop only persisted for 1 or a few seconds and samples on which the drop persisted for more than $1000 \mathrm{~s}$.

\section{Discussion}

\subsection{Chemical soil properties}

In general, the Siberian larch has low requirements with respect to chemical soil properties (Dylis, 1947). It can grow on a wide range of soils and may colonise even rather fresh sediments (Timoshok and Skorokhodov, 2014). Siberian larch can also adapt to low nutrient availability by enhanced soil nutrient exploitation (Lebedev, 2012; Chernyshenkî and Vasilyev, 2019). Most importantly, it needs nitrogen (Lebedev, 2010; Chernyshenkî and Vasilyev, 2019), like many other larch species including Larix gmelinii (Schulze et al., 1995; Liang et al., 2014), Larix kaempferi (Leyton, 1956; Kayama et al., 2009), and hybrids such as Larix $\times$ eurolepis (Pâques, 1994). Also, a lack of $\mathrm{K}$ and Mg may limit the growth of larch species on poor, sandy soils (Leyton, 1956; Phu, 1975), whereas growth limitation by insufficient $P$ supply has not yet been reported. Generally, differences in the vitality and growth of larch are more commonly caused by climatic or hydrological differences than by nutrient limitations (Fiedler et al., 1980; Stüber, 1998; Viers et al., 2013).

Because of the low nutrient requirements of Siberian larch, and since we did not detect any significant differences in the chemical properties of soils under disturbed forest with regrowth of trees (DWIR) and under disturbed forest showing no regrowth of trees (DNOR), we conclude that chemical soil properties are not responsible for the differences in postdisturbance regrowth of Siberian larch in our study area. The uppermost $10 \mathrm{~cm}$ of the soils under FOR had even significantly smaller $\mathrm{N}$ stocks and lower contents of exchangeable $\mathrm{Ca}, \mathrm{Mg}$, and $\mathrm{K}$ than the uppermost $10 \mathrm{~cm}$ of the soils under DNOR. Nevertheless, saplings and young trees were growing in the FOR areas, which confirms that the nutrient supply of all analysed soils fulfilled the needs of Siberian larch. Also, nutrient stocks were similar to, or even higher than, those reported from other Siberian larch forests and from forests of other larch species (Kayama et al., 2009; Watanabe et al., 2012; Wang et al., 2014).

\subsection{Physical soil properties and soil hydrology}

Soils under DWIR had significantly more silt and clay and, thus, higher plant-available field capacity than soils under DNOR, which were considerably sandier (Fig. 4). As mean annual precipitation in Tosontsengel is only $200-250 \mathrm{~mm}$, lack of water represents a major limitation for tree growth (Dulamsuren et al., 2011; Chenlemuge et al., 2015). Under these climatic conditions, it is plausible that silt and clay content and the corresponding plant-available field capacity are key factors controlling the post-disturbance tree regrowth pattern. The similarity in the silt and clay contents of soils under DNOR and soils under STE (no significant difference in Fig. 4) points to a potential risk of DNOR sites to permanently shift to steppe vegetation. Such a potential shift has 

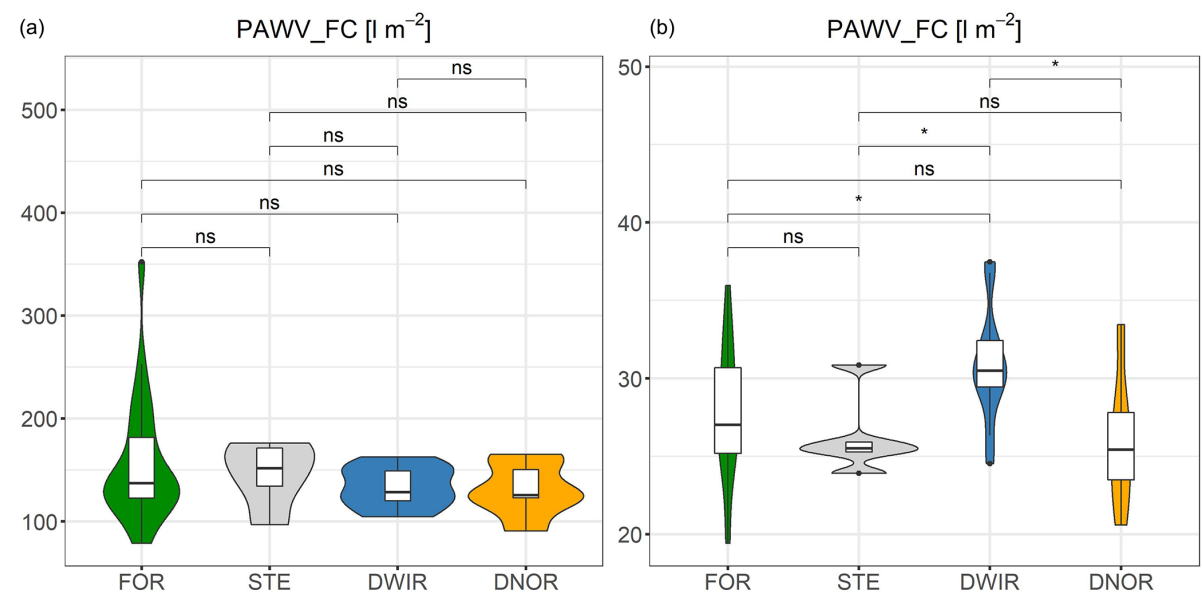

Figure 8. Calculated plant-available water volume at field capacity $\left(\mathrm{PAWV} \mathrm{FC}_{\mathrm{FC}}\right.$ ) per square metre stored in entire soil profiles (a) and stored in only the uppermost $10 \mathrm{~cm}$ of soil profiles (b) under the following four vegetation categories: near-natural forest (FOR; green), steppe close to forest (STE; grey), disturbed forest with regrowth of trees (DWIR; blue), and disturbed forest showing no regrowth of trees (DNOR; orange). $n=49$, and $P$ values were calculated for differences between the arithmetic means (ns $-p>0.05 ;{ }^{*}-p \leq 0.05 ;{ }^{* *}-p \leq 0.01$; $\left.{ }^{* * *}-p \leq 0.001 ;{ }^{* * *}-p \leq 0.0001\right)$. Horizontal bars are medians, boxes are first and third quartiles, points are outliers, and violins are data distributions.

already been predicted for the forest steppe in the Khentey Mountains, Mongolia (Dulamsuren and Hauck, 2008; Dulamsuren et al., 2009).

Measured plant-available field capacities confirmed the difference between soils under DWIR and DNOR. Calculated PAWV $V_{\mathrm{FC}}$ further underscored the crucial role of soil water storage for post-disturbance tree regrowth under the given climatic conditions. With respect to PAWV $\mathrm{FC}_{\mathrm{FC}}$ of the whole soil profiles, the absence of any significant differences between the four vegetation categories (Fig. 8a) is in accordance with the fact that mature trees were originally able to grow on all of these north-facing slopes prior to a severe disturbance. With respect to the uppermost $10 \mathrm{~cm}$ of the soils, the significantly higher PAWV $\mathrm{FC}_{\mathrm{FC}}$ under DWIR compared to soils under all other vegetation categories (Fig. 8b) highlights the importance of water storage in the uppermost centimetres for the re-establishment and survival of seedlings after severe forest disturbance, which is the precondition for postdisturbance forest recovery. The very wide $\mathrm{PAWV}_{\mathrm{FC}}$ range in the uppermost $10 \mathrm{~cm}$ of soils under FOR suggests that these FOR sites include both sites where seedlings will be able to re-establish after severe disturbance and sites where this will not be possible, which means that, most likely, no forest regrowth will take place if once a severe forest disturbance happens to these sites.

In the site-wise comparison, hydraulic conductivity tended to be higher in the uppermost horizons of soils under DWIR compared to their counterparts under DNOR. Trees may benefit from this difference for two reasons. First, rapid infiltration through the uppermost horizons reduces evaporation loss. Second, grasses and herbs have a dense but shallow root system and compete with tree roots for water at shallow soil depth. As tree roots reach deeper down into the soil, they benefit from rapid water infiltration below the depth of the roots of grasses and herbs. Lange et al. (2015) carried out irrigation experiments on grass-dominated south-facing slopes and forest-dominated north-facing slopes in the Mongolian forest steppe. On south-facing slopes, most of the water was either taken up by grass or evaporated, and the remaining water reached only $5 \mathrm{~cm}$ soil depth. On north-facing slopes, the water percolated down to the permafrost table. Although the contrasting exposition also affected this experiment, these results confirm the competitiveness of grasses for water in the upper soil horizons and the relevance of soil hydraulic conductivity for tree growth in water-limited environments.

We did not detect a positive effect of permafrost on postdisturbance tree regrowth, as permafrost was neither encountered under DWIR nor under DNOR. This is in agreement with observations by Kopp et al. (2014), who reported the absence of permafrost 5 years after severe forest fire. The same authors, moreover, measured increased soil moisture in soils of burned sites, compared to soils under forest, which they attributed to the absence of tree transpiration. In contrast, Park et al. (2009) indicated a decrease in soil moisture after fire and logging, arguing that evaporation loss from the bare soils and deterioration of physical soil properties exceeds the decrease in transpiration. In our study area, we also observed rather decreased soil moisture at sites disturbed by fire and logging, compared to near-natural forest sites. An additional decline in soil moisture after fire can be induced by water repellency that may increase surface runoff (DeBano, 2000; Mataix-Solera and Doerr, 2004). However, we did not observe a significant difference in water repellency between the four vegetation categories, possibly because of the high 


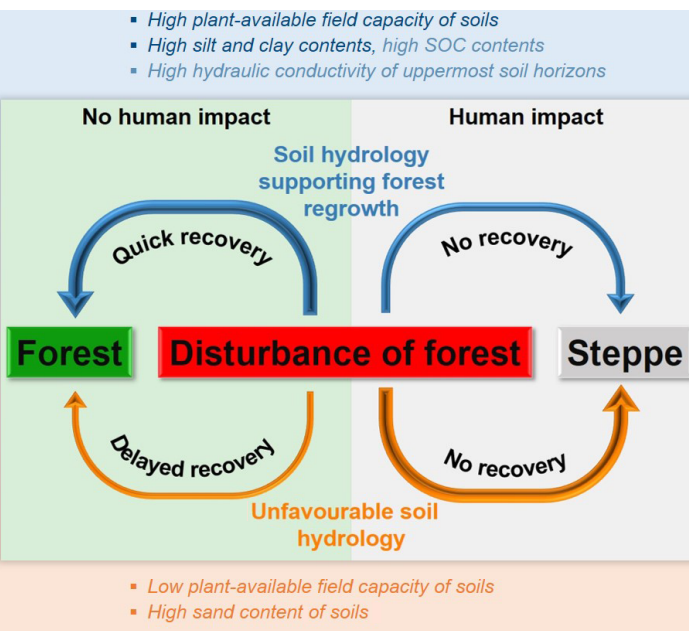

Figure 9. Possible development pathways of disturbed forests in the Mongolian forest steppe, as controlled by soil hydrology and human impact. Soil properties listed in dark blue show the significant positive effect, light blue show the non-significant positive effect, and orange show the significant negative effect.

frequency of fires in our study area and associated enhanced erosion (Goldammer, 2002; Hessl et al., 2012). As water repellency occurred irregularly across the whole study area, including DWIR and DNOR, it seemed to be irrelevant for the post-disturbance tree recovery pattern in our study area.

\subsection{Further relevant environmental factors}

Other factors besides soil hydrology that influence the postdisturbance tree regrowth pattern include in particular relief and human activity. Relief-induced water gains in concave positions may support tree growth even where soil properties seem to be unfavourable. Similarly, water losses through divergence in convex positions may hamper tree growth, even where soil properties seem to be suitable. Also, small tree patches that survived a disturbance can have a positive influence on post-disturbance tree regrowth. In our study area, we observed enhanced fructification of trees that had survived forest fires, initiating tree regrowth in belts around small tree patches that had persisted. We explain this observation by the shading of the remaining adult trees that reduces evaporation and creates a more even microclimate on the ground and by the increased availability of intact seeds in the direct surrounding of mature trees (Dugarjav, 2006).

In contrast, human activity, especially logging and pastoral pressure, may inhibit post-disturbance forest recovery (Khishigjargal et al., 2013; Dulamsuren et al., 2014; Khansaritoreh et al., 2017b). In particular, goats grazing in areas of burned forest or in forest stands that have previously been opened by partial logging, hamper the growth of seedlings and damage young trees (Sankey et al., 2006). Thus, human impact and soil hydrology are the two key fac- tors controlling the post-disturbance tree regrowth pattern (Fig. 9). This is the outcome of this work, and relates to moderate and severe disturbances in our study area, which lead to deforested areas showing diverse tree regrowth. Differences in tree regrowth between moderate and severe disturbances were not detected. The observed low disturbances did not have considerable effects on the forests.

Loss of the shading by the forest canopy, the forest microclimate, and the insulating organic layer, in turn, leads to permafrost degradation. Also, the ongoing climate change accelerates permafrost decline in Mongolia. Thus, this essential soil water reservoir is likely to disappear (Sharkhuu and Sharkhuu, 2012). As the meltwater from the active layer above the permafrost table can support tree growth even at sites where soil water storage is below the threshold for tree growth, permafrost decline may also contribute to the decrease in forest area in the Mongolian forest steppe. In some of our investigated sites, this has already happened.

Klinge et al. (2020) estimated that the potential forest distribution in the Khangai Mountains is 3 times larger than the actual forest area. This discrepancy indicates that forest fire and human activity already caused a considerable decline in forested areas.

\section{Conclusions}

This study showed that the post-disturbance regrowth pattern of forests in the central Mongolian forest steppe, a highly sensitive, semi-arid landscape, is largely controlled by soil hydrology. With respect to our hypotheses established in the beginning of this paper, we conclude with the following:

1. Differences in post-disturbance tree regrowth depend mainly on the texture of the uppermost soil horizons. Loamy soils have high plant-available field capacity and are, thus, able to store sufficient amounts of water for post-disturbance re-establishment of seedlings as a precondition for forest regrowth. In contrast, sandy soils cannot store enough water for the re-establishment of seedlings and subsequent recovery of tree vegetation under the present environmental conditions.

2. Post-disturbance tree regrowth may be supported by higher hydraulic conductivity in the uppermost soil horizons, as rapid percolation through the upper soil horizons reduces evaporation loss. In addition, trees benefit from the reduced competition for water with grasses and herbs that results from rapid water percolation into the subsoil.

3. Nutrient limitation is not relevant for the uneven postdisturbance tree regrowth pattern in our study area, as the dominant tree species, Siberian larch, has rather low nutrient requirements.

4. Meltwater from the active layer above the permafrost table provides additional water for near-natural forests. 
However, it cannot be a relevant factor for the uneven post-disturbance regrowth pattern of Siberian larch in our study area because permafrost was not encountered under disturbed forests either with or without tree regrowth.

Under the given climatic conditions, water limitation is the predominant factor controlling tree growth in the semiarid Mongolian forest steppe. Therefore, even small differences in soil properties that lead to an increase in the amount of plant-available water can be decisive for post-disturbance tree regrowth.

Disturbances by severe fire or clear-cutting result in a loss of permafrost and, thus, the loss of an additional water reservoir during summer. Such an additional water source can be critical at sites where soil water storage alone is slightly below the threshold for tree growth. Therefore, such sites are particularly prone to an irreversible shift from forest to steppe after a strong disturbance involving loss of permafrost. Moreover, we expect that many sites where soil hydrology allows for post-disturbance tree regrowth under the present climatic conditions will lose their ability for post-disturbance forest recovery in the course of the ongoing climate change, as the present conditions are very close to the threshold for forest growth, and already a minor change may lead to a fall below this threshold.

Climate projections predict that the decrease in permafrost will continue, and drought events will become both more frequent and more intensive. At the same time, it seems unlikely that the pressure on forests in the Mongolian forest steppe by fire, logging, and grazing will decrease, unless explicit and effective measures are taken. The consequences of this unfavourable interplay will most likely include a decrease in the growth rates of trees and a further considerable and irreversible decline in forested area. Therefore, the regulation of the human impact on the forests in the Mongolian forest steppe is mandatory if a further irreversible loss of forest area is to be avoided. 


\section{Appendix A}
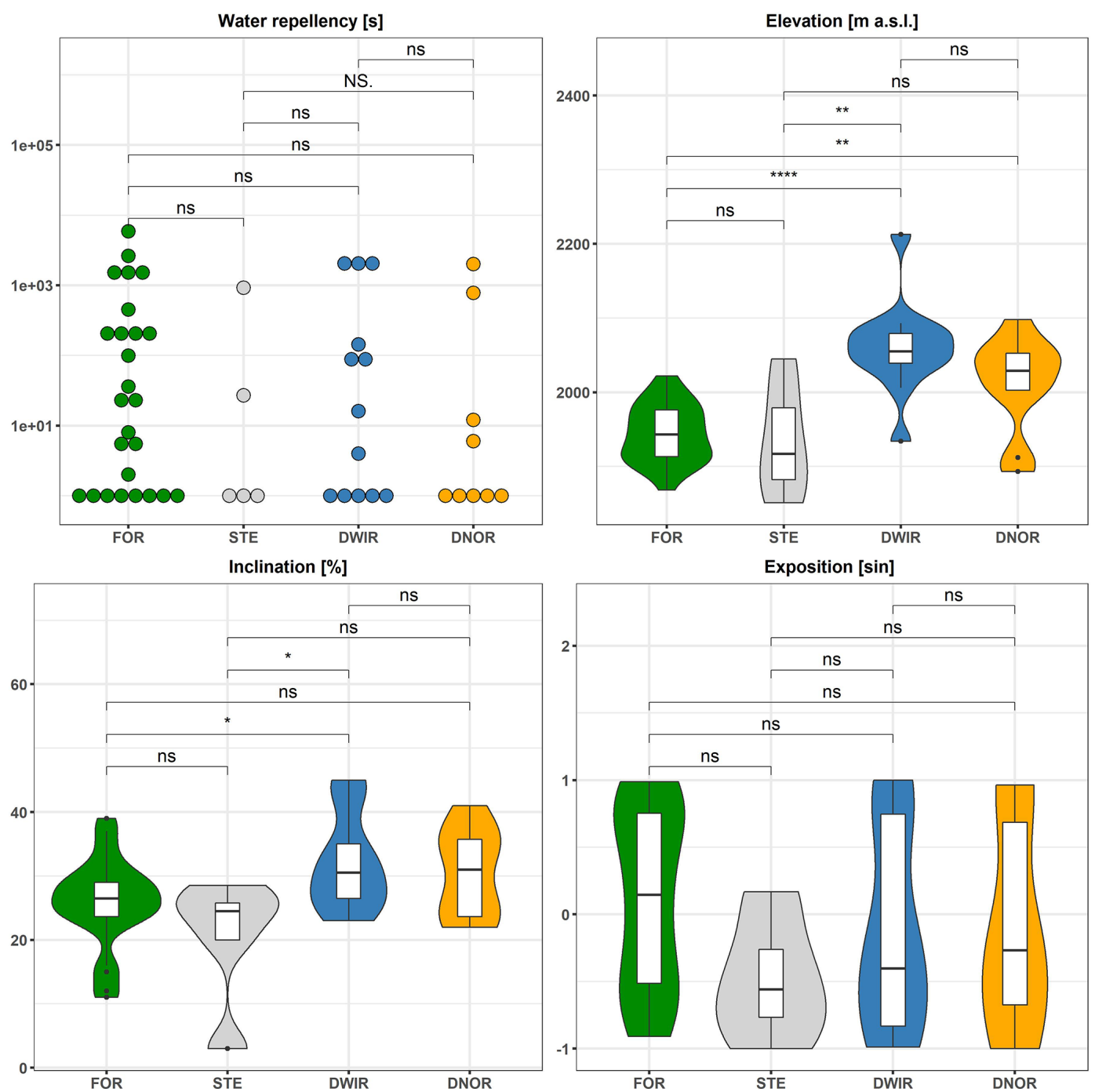

Figure A1. Scatterplots for water repellency (expressed as water drop infiltration time in seconds; $n=53$ ) and violin plots and box plots for the elevation $(n=54)$, inclination $(n=54)$, and exposition $(n=54)$ of the soils under the four vegetation categories of near-natural forest (FOR; green), steppe close to forest (STE; grey), disturbed forest with regrowth of trees (DWIR; blue), and disturbed forest showing no regrowth of trees (DNOR; orange). $P$ values were calculated for differences between the arithmetic means (NS $-p=1 ;$ ns $-p>0.05$; *: $p \leq 0.05$; $^{* *}-p \leq 0.01$ * $\left.^{* *}-p \leq 0.001 ;^{* * * *}-p \leq 0.0001\right)$. Horizontal bars are medians, boxes are first and third quartiles, points are outliers, and violins are data distributions. 


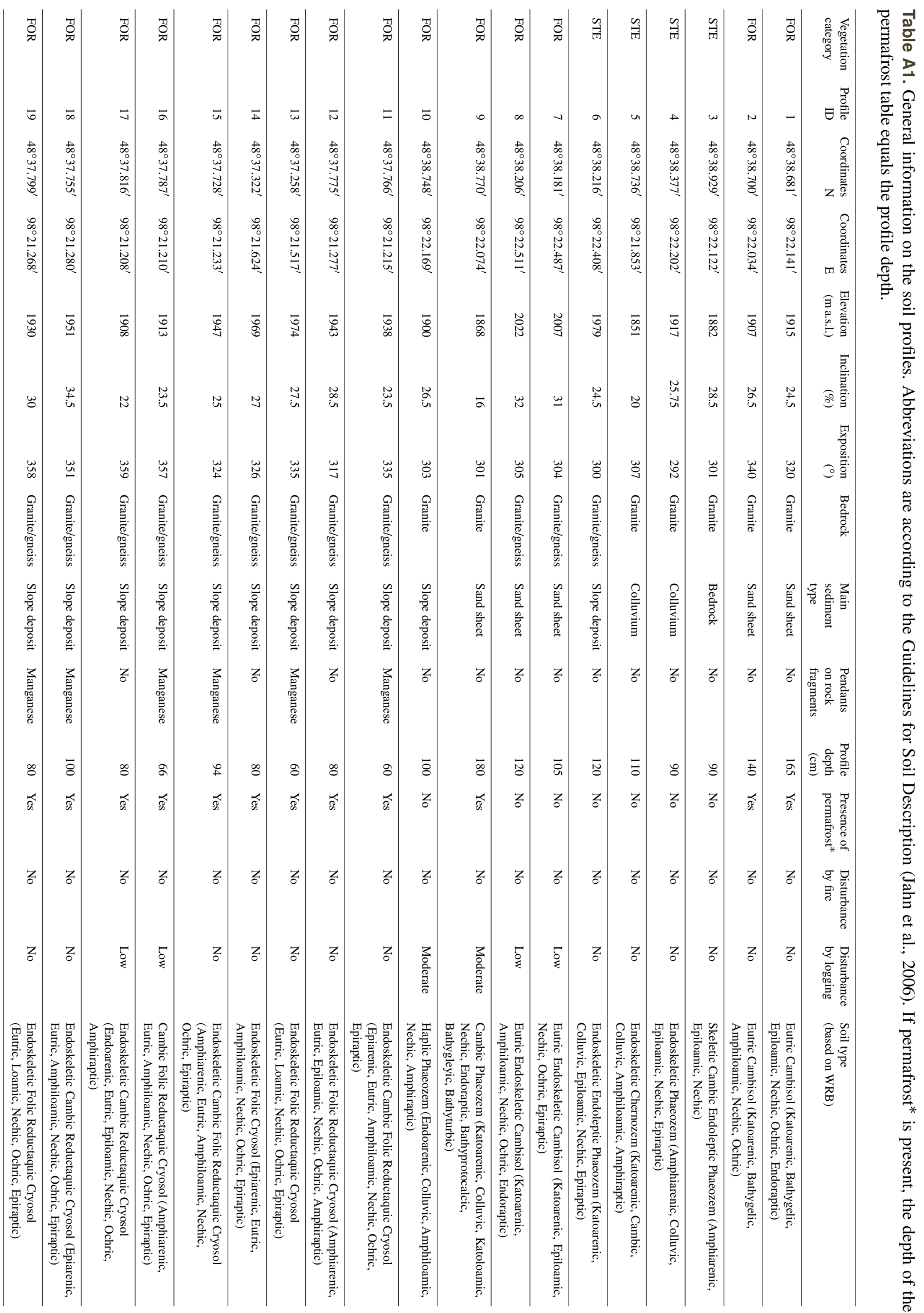



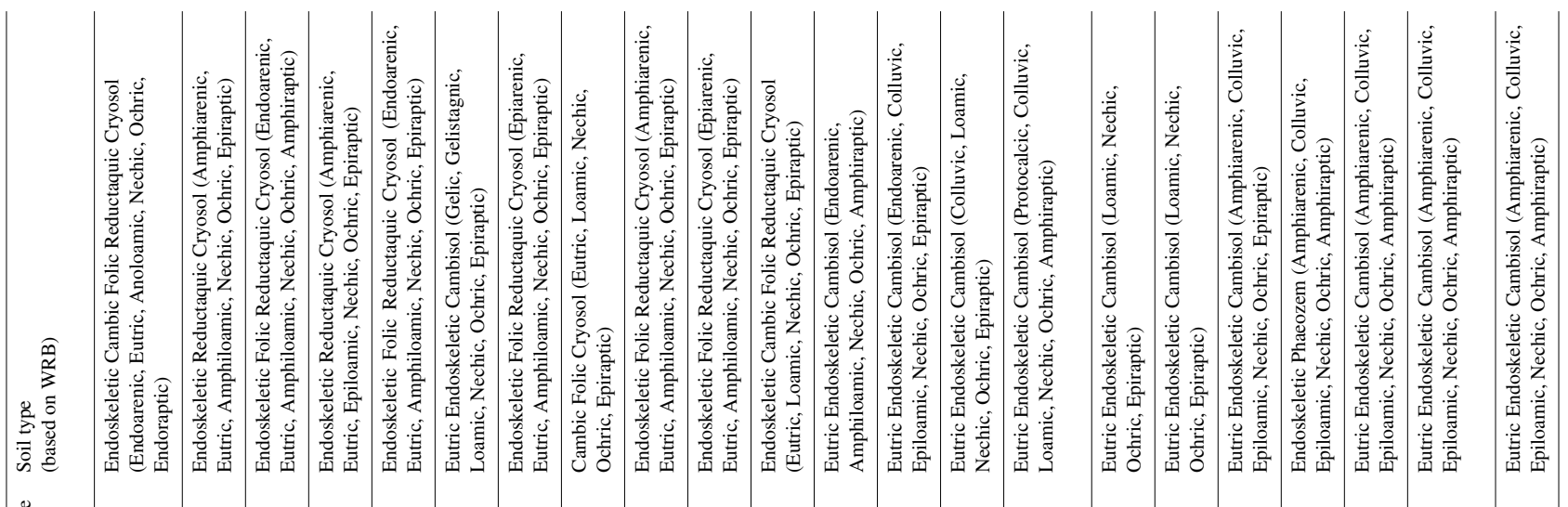

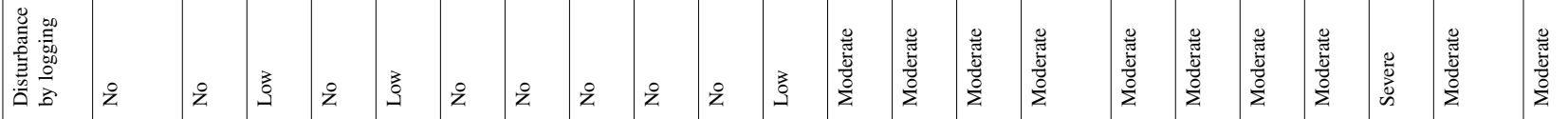

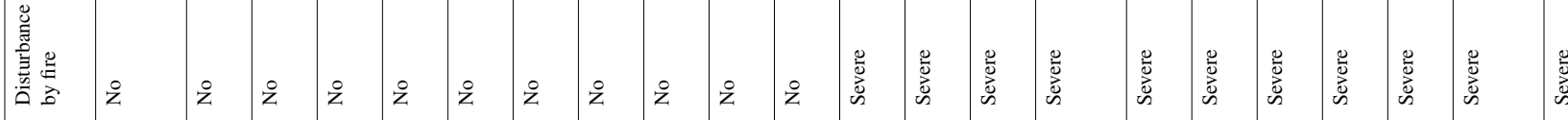

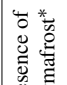

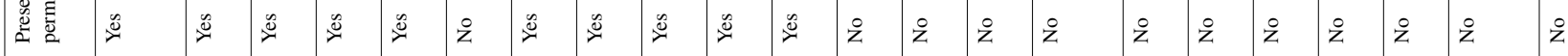

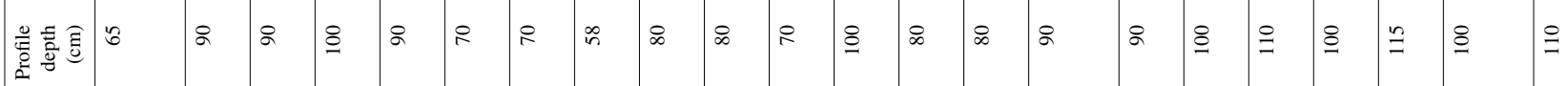

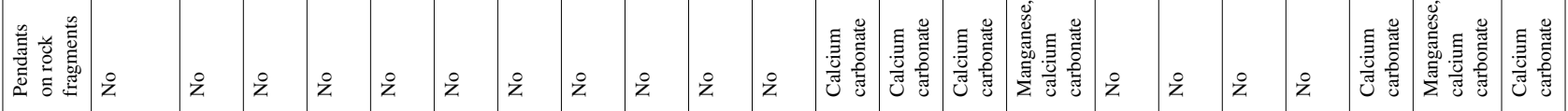

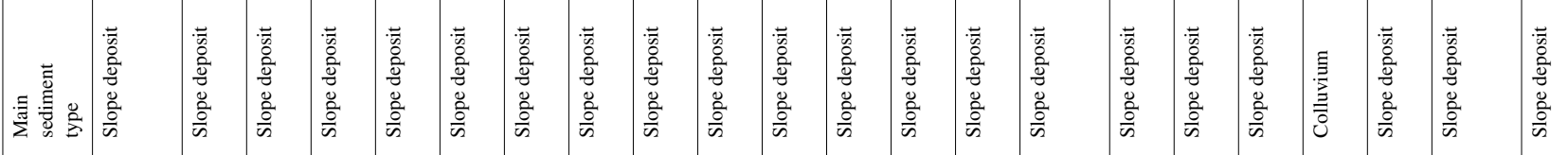

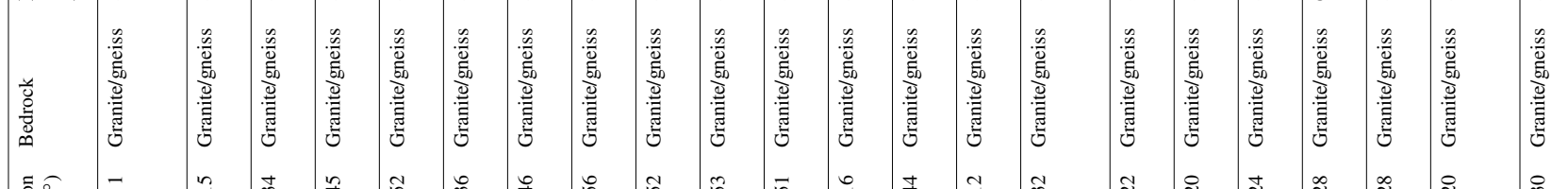
喜 -

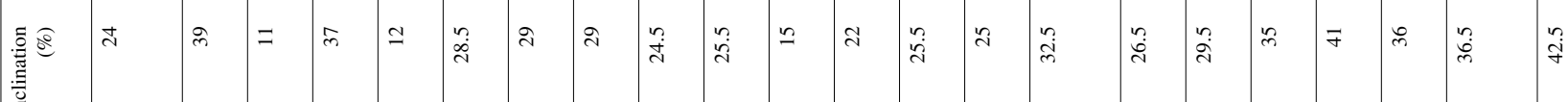
总

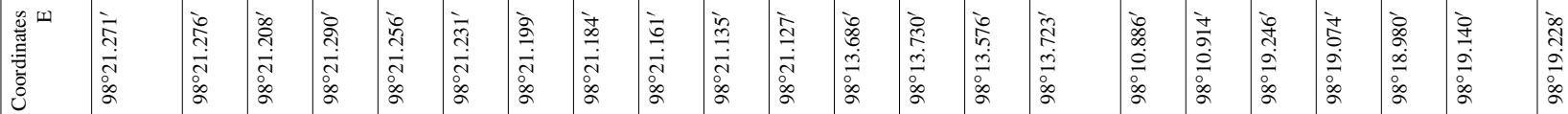

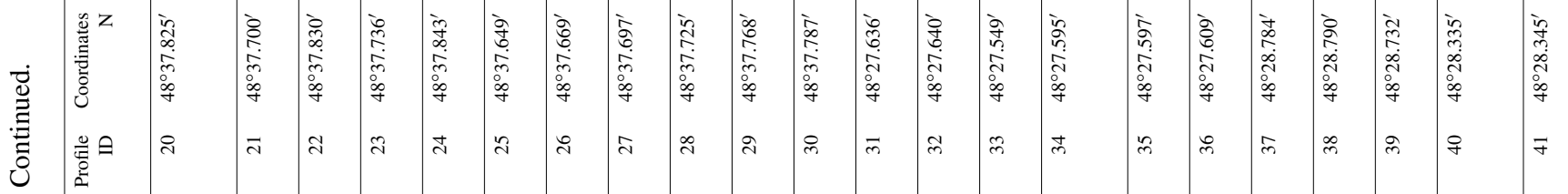

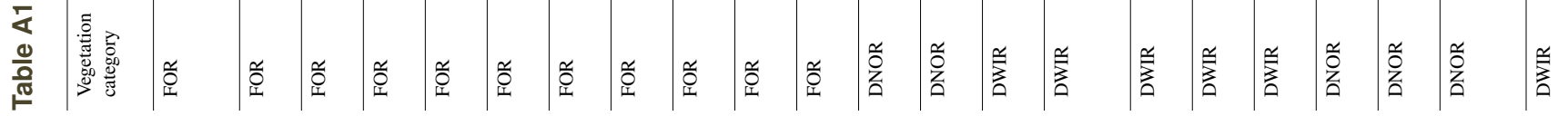




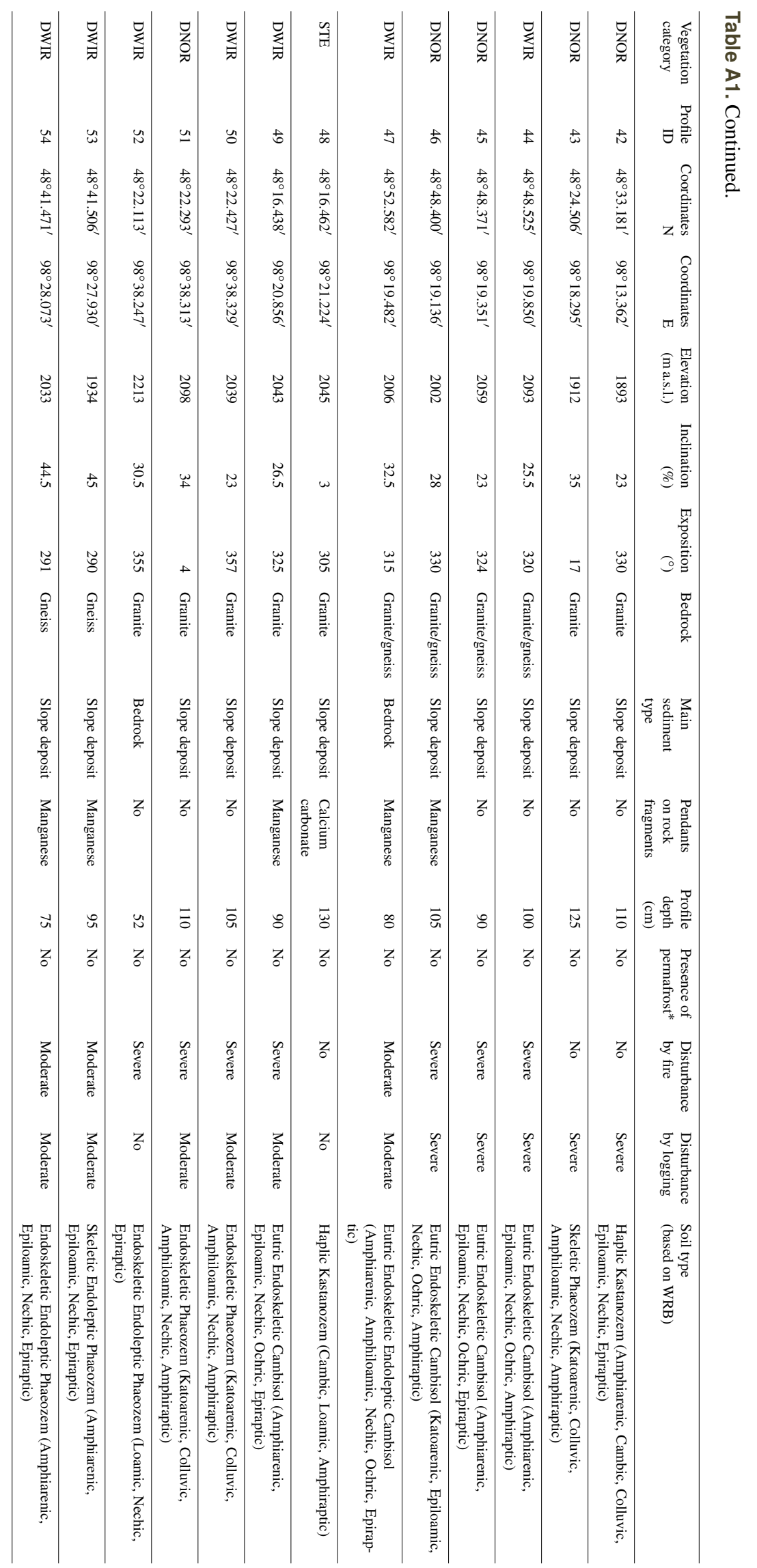


Code and data availability. Data sets can be found in the Supplement.

Supplement. The supplement related to this article is available online at: https://doi.org/10.5194/soil-7-563-2021-supplement.

Author contributions. MK and DS designed the research project. All authors carried out the fieldwork together. FS, TP, and JB carried out the laboratory work. FS prepared the paper with contributions from all co-authors, especially from DS and MK.

Competing interests. The authors declare that they have no conflict of interest.

Disclaimer. Publisher's note: Copernicus Publications remains neutral with regard to jurisdictional claims in published maps and institutional affiliations.

Acknowledgements. We thank Choimaa Dulamsuren and Uudus Bayarsaikhan, for their invaluable help in organising and conducting our fieldwork, and Daramragchaa Tuya, for her great support of our research. We are also grateful to our Mongolian colleagues Mr. Amarbayasgalan, Mr. Enkhjargal, Mr. Enkh-Agar, and Ms. Munkhtuya; we appreciated their hospitality and help with the fieldwork. Our thanks also go to the German students Janin Klaassen, Kim Lena Arndt, and Tim Rollwage, for their great commitment during the fieldwork in Mongolia. Furthermore, we want to thank Jürgen Grotheer, Petra Voigt, Anja Södje, and Eike Sebode, for their excellent work in the laboratory. We also thank Lukáš Banyi for the essential support in using the R project for statistical computing.

Financial support. This research has been supported by the Deutsche Forschungsgemeinschaft (grant no. 385460422).

Review statement. This paper was edited by Nikolaus J. Kuhn and reviewed by three anonymous referees.

\section{References}

Academy of Sciences of Mongolia: Academy of Sciences of USSR: National Atlas of the Peoples Republic of Mongolia, Ulaanbaatar, Moscow, 1990.

Albenskiy, A. V., Krylov, G. V., Logginov, B. J., and Scherlin, J. D.: Usage of fast growing breeds in field protection forest cultivation, Moskow, 1956 (in Russian).

Allen, C. D., Macalady, A. K., Chenchouni, H., Bachelet, D., McDowell, N., Vennetier, M., Kitzberger, T., Rigling, A., Breshears, D. D., Hogg, E. H., Gonzalez, P., Fensham, R., Zhang, Z., Castro, J., Demidova, N., Lim, J.-H., Allard, G., Run- ning, S. W., Semerci, A., and Cobb, N.: A global overview of drought and heat-induced tree mortality reveals emerging climate change risks for forests, Forest Ecol. Manag., 259, 660684, https://doi.org/10.1016/j.foreco.2009.09.001, 2010.

Amoozegar, A. and Warrick, A. W.: Hydraulic Conductivity of Saturated Soils: Field Methods, American Socienty of Agronomy-Soil Science Society of America, 735-770, https://doi.org/10.2136/sssabookser5.1.2ed.c29, 1986.

Batima, P., Natsagdorj, L., Gombluudev, P., and Erdenetsetseg, B.: Observed climate change in Mongolia, Assessments of Impacts and Adaptations of Climate Change, 1-26, available at: http://www.start.org/Projects/AIACC_Project/working_ papers/WorkingPapers/AIACC_WP_No013.pdf (last access: 17 July .2020), 2005.

Beaudette, D. E., Roudier, P., and O'Geen, A. T.: Algorithms for quantitative pedology: A toolkit for soil scientists, Comput. Geosci., 52, 258-268, https://doi.org/10.1016/j.cageo.2012.10.020, 2013.

Bonan, G. B. and Shugart, H. H.: Environmental Factors and Ecological Processes in Boreal Forests, Ann. Rev. Ecol. Evolut. Syst., 20, 1-28, 1989.

Chenlemuge, T., Schuldt, B., Dulamsuren, C., Hertel, D., Leuschner, C., and Hauck, M.: Stem increment and hydraulic architecture of a boreal conifer (Larix sibirica) under contrasting macroclimates, Trees, 29, 623-636, https://doi.org/10.1007/s00468-014-1131-x, 2015.

Chernyshenkî, O. V. and Vasilyev, S. B.: Mineral nutrition specificity of coniferous trees on industrial waste discharge of Egorievsk phosphorite deposit, Forest. Bull., 4653, https://doi.org/10.18698/2542-1468-2019-5-46-53, 2019 (in Russian).

Churakova, O. V., Shashkin, A. V., Siegwolf, R. T. W., Spahni, R., Launois, T., Saurer, M., Bryukhanova, M. V., Benkova, A. V., Kuptsova, A. V., Peylin, P., Vaganov, E. A., MassonDelmotte, V., and Roden, J.: Application of eco-physiological models to the climatic interpretation of $\delta^{13} \mathrm{C}$ and $\delta^{18} \mathrm{O}$ measured in Siberian larch tree-rings, Dendrochronologia, 39, 51-59, https://doi.org/10.1016/j.dendro.2015.12.008, 2016.

Dashkhuu, D., Kim, J. P., Chun, J. A., and Lee, W.S.: Long-term trends in daily temperature extremes over Mongolia, Weather Clim. Extrem., 8, 26-33, https://doi.org/10.1016/j.wace.2014.11.003, 2015.

Dashtseren, A., Ishikawa, M., Iijima, Y., and Jambaljav, Y.: Temperature Regimes of the Active Layer and Seasonally Frozen Ground under a Forest-Steppe Mosaic, Mongolia, Permafrost Perigl. Process., 25, 295-306, https://doi.org/10.1002/ppp.1824, 2014.

DeBano, L.: The role of fire and soil heating on water repellency in wildland environments: a review, J. Hydrol., 231/232, 195-206, https://doi.org/10.1016/S0022-1694(00)00194-3, 2000.

Doerr, S. H.: On standardizing the "Water Drop Penetration Time" and the "Molarity of an Ethanol Droplet" techniques to classify soil hydrophobicity: A case study using medium textured soils, Earth Surf. Process. Land., 23, 663-668, 1998.

Doerr, S. H., Shakesby, R. A., and Walsh, R.: Soil water repellency: its causes, characteristics and hydrogeomorphological significance, Earth-Sci. Rev., 51, 33-65, https://doi.org/10.1016/S0012-8252(00)00011-8, 2000. 
Dugarjav, C.: Larch forests of Mongolia (in Mongolian), Bembi San, Ulan Bator, 2006.

Dulamsuren, C. and Hauck, M.: Spatial and seasonal variation of climate on steppe slopes of the northern Mongolian mountain taiga, Grassland Science, 54, 217-230, https://doi.org/10.1111/j.1744-697X.2008.00128.x, 2008.

Dulamsuren, C., Hauck, M., Bader, M., Osokhjargal, D., Oyungerel, S., Nyambayar, S., Runge, M., and Leuschner, C.: Water relations and photosynthetic performance in Larix sibirica growing in the forest-steppe ecotone of northern Mongolia, Tree Physiol., 29, 99-110, https://doi.org/10.1093/treephys/tpn008, 2009.

Dulamsuren, C., Hauck, M., and Leuschner, C.: Recent drought stress leads to growth reductions in Larix sibirica in the western Khentey, Mongolia, Glob. Change Biol., 95, 3024-3035, https://doi.org/10.1111/j.1365-2486.2009.02147.x, 2010.

Dulamsuren, C., Hauck, M., Leuschner, H. H., and Leuschner, C.: Climate response of tree-ring width in Larix sibirica growing in the drought-stressed forest-steppe ecotone of northern Mongolia, Ann. Forest Sci., 68, 275-282, https://doi.org/10.1007/s13595011-0043-9, 2011.

Dulamsuren, C., Khishigjargal, M., Leuschner, C., and Hauck, M.: Response of tree-ring width to climate warming and selective logging in larch forests of the Mongolian Altai, J. Plant Ecol., 7, 24-38, https://doi.org/10.1093/jpe/rtt019, 2014.

Dylis, N. V.: Siberian larch, Moscow Society of Nature Investigators, Moskow, 63-89, 1947 (in Russian).

Fiedler, H. J., Hunger, W., Müller, K., and Skodawessely, K.: $\mathrm{Zu}$ den Beziehungen zwischen Boden, Ernährungszustand und Wuchsleistung bei Lärche (Larix decidua Mill.), Flora, 170, 1-19, https://doi.org/10.1016/S0367-2530(17)31187-8, 198 (in German)0.

Goldammer, J. G.: Fire Situation in Mongolia (IFFN No. 26) GFMC, available at: http://gfmc.online/iffn/country/mn/mn_11. html (last access: 14 October 2019), 2002.

Grunert, J., Lehmkuhl, F., and Walther, M.: Paleoclimatic evolution of the Uvs Nuur basin and adjacent areas (Western Mongolia), Quaternary Int., 65/66, 171-192, https://doi.org/10.1016/S10406182(99)00043-9, 2000.

Gupta, S. C. and Larson, W. E.: Estimating soil water retention characteristics from particle size distribution, organic matter percent, and bulk density, Water Resour. Res., 15, 1633-1635, https://doi.org/10.1029/WR015i006p01633, 1979.

Haase, G.: Die Höhenstufen der Böden im Changai (MVR) (in German), Zeitschrift für Pflanzenernährung, Düngung, Bodenkunde, 102, 113-127, https://doi.org/10.1002/jpln.19631020205, 1963.

Hais, M., Chytrý, M., and Horsák, M.: Exposure-related forest-steppe: A diverse landscape type determined by topography and climate, J. Arid Environ., 135, 75-84, https://doi.org/10.1016/j.jaridenv.2016.08.011, 2016.

Hessl, A. E., Ariya, U., Brown, P., Byambasuren, O., Green, T. R., Jacoby, G. C., Sutherland, E. K., Nachin, B., Maxwell, R. S., Pederson, N., Grandpré, L. de, Saladyga, T., and Tardif, J. C.: Reconstructing fire history in central Mongolia from tree-rings, Int. J. Wildland Fire, 21, 86, https://doi.org/10.1071/WF10108, 2012.

Hessl, A. E., Brown, P., Byambasuren, O., Cockrell, S., Leland, C., Cook, E. R., Nachin, B., Pederson, N., Saladyga, T., and Suran, B.: Fire and climate in Mongolia (1532-
2010 Common Era), Geophys. Res. Lett., 43, 6519-6527, https://doi.org/10.1002/2016GL069059, 2016.

Hilbig, W.: Zur Problematik der ursprünglichen Waldverbreitung in der Mongolischen Volksrepublik Ergebnisse der Mongolisch - Deutschen Biologischen Expeditionen seit 1962, Nr. 181, Flora, 179, 1-15, https://doi.org/10.1016/S0367-2530(17)30213X, 1987 (in German).

Ishikawa, M., Sharkhuu, N., Zhang, Y., Kadota, T., and Ohata, T.: Ground Thermal and Moisture Conditions at the Southern Boundary of Discontinuous Permafrost, Mongolia, Permafrost Perigl. Process., 16, 209-216, https://doi.org/10.1002/ppp.483, 2005.

IUSS Working Group WRB: World reference base for soil resources 2014: International soil classification system for naming soils and creating legends for soil maps, World soil resources reports, 106, FAO, Rome, 181 pp., 2015.

Jahn, R., Blume, H.-P., Asio, V. B., Spaargaren, O., and Schad, P. (Eds.): Guidelines for soil description, 4., FAO, Rome, 97 pp., 2006.

Kapper, O. G.: Conifer Species: Forestry Characteristics, Moskow, Leningrad, 1954 (in Russian).

Kassambara, A.: ggpubr: "ggplot2" Based Publication Ready Plots [code], available at: https://mran.microsoft.com/snapshot/ 2017-04-22/web/packages/ggpubr/ggpubr.pdf (last access: 20 August 2020) 2019.

Kassambara, A. and Mundt, F.: Extract and Visualize the Results of Multivariate Data Analyses [code], available at: https://cran.microsoft.com/snapshot/2016-11-30/web/packages/ factoextra/factoextra.pdf (last access: 20 August 2020), 2019.

Kayama, M., Makoto, K., Nomura, M., Satoh, F., and Koike, T.: Nutrient dynamics and carbon partitioning in larch seedlings (Larix kaempferi) regenerated on serpentine soil in northern Japan, Landscape Ecol. Eng., 5, 125-135, https://doi.org/10.1007/s11355-009-0069-4, 2009.

Khansaritoreh, E., Dulamsuren, C., Klinge, M., Ariunbaatar, T., Bat-Enerel, B., Batsaikhan, G., Ganbaatar, K., Saindovdon, D., Yeruult, Y., Tsogtbaatar, J., Tuya, D., Leuschner, C., and Hauck, M.: Higher climate warming sensitivity of Siberian larch in small than large forest islands in the fragmented Mongolian forest steppe, Glob. Change Biol., 23, 3675-3689, https://doi.org/10.1111/gcb.13750, 2017a.

Khansaritoreh, E., Eldarov, M., Ganbaatar, K., Saindovdon, D., Leuschner, C., Hauck, M., and Dulamsuren, C.: Age structure and trends in annual stem increment of Larix sibirica in two neighboring Mongolian forest-steppe regions differing in land use history, Trees, 31, 1973-1986, https://doi.org/10.1007/s00468-017-1601-z, 2017b.

Kharuk, V. I., Ranson, K. J., and Dvinskaya, M. L.: Wildfires dynamic in the larch dominance zone, Geophys. Res. Lett., 35, 1-6, https://doi.org/10.1029/2007GL032291, 2008.

Khishigjargal, M., Dulamsuren, C., Lkhagvadorj, D., Leuschner, C., and Hauck, M.: Contrasting responses of seedling and sapling densities to livestock density in the Mongolian forest-steppe, Plant Ecol., 214, 1391-1403, https://doi.org/10.1007/s11258013-0259-x, 2013.

Klinge, M. and Lehmkuhl, F.: Geomorphology of the Tsetseg Nuur basin, Mongolian Altai - lake development, fluvial sedimentation and aeolian transport in a semi-arid environment, J. Maps, 9, 361-366, https://doi.org/10.1080/17445647.2013.783513, 2013. 
Klinge, M., Dulamsuren, C., Erasmi, S., Karger, D. N., and Hauck, M.: Climate effects on vegetation vitality at the treeline of boreal forests of Mongolia, Biogeosciences, 15, 1319-1333, https://doi.org/10.5194/bg-15-1319-2018, 2018.

Klinge, M., Dulamsuren, C., Schneider, F., Erasmi, S., Hauck, M., Bayarsaikhan, U., and Sauer, D.: Modelled potential forest area in the forest-steppe of central Mongolia is about three times of actual forest area, Biogeosciences Discuss. [preprint], https://doi.org/10.5194/bg-2020-13, 2020.

Klinge, M., Schneider, F., Dulamsuren, C., Arndt, K., Bayarsaikhan, U., and Sauer, D.: Interrelations between vegetation, natural and anthropogenic disturbances, and discontinuous permafrost in the forest-steppe of central Mongolia, under revision, Earth Surf. Proc. Land., 46, 1766-1782, 2021.

Kopp, B. J., Minderlein, S., and Menzel, L.: Soil Moisture Dynamics in a Mountainous Headwater Area in the Discontinuous Permafrost Zone of northern Mongolia, Arct. Antarct. Alp. Res., 46, 459-470, https://doi.org/10.1657/1938-4246-46.2.459, 2014.

Krasnoshchekov, Y. N.: Soil cover of mountain forests in the East Khubsugul region of Mongolia, Eurasian Soil Sci., 41, 694-703, https://doi.org/10.1134/S106422930807003X, 2008.

Krasnoshchekov, Y. N.: Soils and the Soil Cover of Mountainous Tundra and Forest Landscapes in the Central Khangai of Mongolia, Eurasian Soil Sci., 43, 117-126, https://doi.org/10.1134/S1064229310020018, 2010.

Lange, J., Kopp, B. J., Bents, M., and Menzel, L.: Tracing variability of run-off generation in mountainous permafrost of semiarid north-eastern Mongolia, Hydrol. Process., 29, 1046-1055, https://doi.org/10.1002/hyp.10218, 2015.

Lê, S., Josse, J., and Husson, F.: FactoMineR: An R Package for Multivariate Analysis, J. Stat. Softw., 25, 1-18, 2008.

Lebedev, E. V.: Impact of nitrogen forms on photosynthesis, mineral nutrition and biological productivity of plants as Siberian larch and European spruce, Forestry Bull., 6, 14-18, 2010 (in Russian).

Lebedev, E. V.: Quantitative Measurements of Net Productivity of Photosynthesis, Mineral Nutrition and Biological Productivity of Larix sibirica During Ontogenesis in the Areal of Southern Altai, Herald of Altai state agricultural university, 12, 61-66, 2012 (in Russian).

Lehmkuhl, F. and Haselein, F.: Quaternary paleoenvironmental change on the Tibetan Plateau and adjacent areas (Western China and Western Mongolia), Quaternary Int., 65/66, 121-145, https://doi.org/10.1016/S1040-6182(99)00040-3, 2000.

Lehmkuhl, F., Hilgers, A., Fries, S., Hülle, D., Schlütz, F., Shumilovskikh, L., Felauer, T., and Protze, J.: Holocene geomorphological processes and soil development as indicator for environmental change around Karakorum, Upper Orkhon Valley (Central Mongolia), CATENA, 87, 31-44, https://doi.org/10.1016/j.catena.2011.05.005, 2011.

Leyton, L.: The relationship between the growth and mineral composition of the foliage of Japanese larch (Larix leptolepis Murr.), Plant Soil, 7, 167-177, https://doi.org/10.1007/BF01343725, 1956.

Liang, M., Sugimoto, A., Tei, S., Bragin, I. V., Takano, S., Morozumi, T., Shingubara, R., Maximov, T. C., Kiyashko, S. I., Velivetskaya, T. A., and Ignatiev, A. V.: Importance of soil moisture and $\mathrm{N}$ availability to larch growth and distribution in the Arctic taiga-tundra boundary ecosystem, northeastern Siberia, Po- lar Sci., 8, 327-341, https://doi.org/10.1016/j.polar.2014.07.008, 2014.

Lkhagvadorj, D., Hauck, M., Dulamsuren, C., and Tsogtbaatar, J.: Twenty Years After Decollectivization: Mobile Livestock Husbandry and Its Ecological Impact in the Mongolian Forest-Steppe, Human Ecol., 41, 725-735, https://doi.org/10.1007/s10745-013-9599-3, 2013.

Mataix-Solera, J. and Doerr, S. H.: Hydrophobicity and aggregate stability in calcareous topsoils from fire-affected pine forests in southeastern Spain, Geoderma, 118, 77-88, https://doi.org/10.1016/S0016-7061(03)00185-X, 2004.

Maximovich, S. V.: Geography and Ecology of Cryogenic Soils of Mongolia, in: Cryosols: Permafrost-Affected Soils, edited by: Kimble, J. M., Springer, Berlin, Heidelberg, 253-274, https://doi.org/10.1007/978-3-662-06429-0_13, 2004.

Nandintsetseg, B. and Shinoda, M.: Seasonal change of soil moisture in Mongolia: its climatology and modelling, Int. J. Climatol., 31, 1143-1152, https://doi.org/10.1002/joc.2134, 2011.

Opp, C. and Hilbig, W.: Regular distribution patterns of soils and plant communities in northern Central Asia with special consideration of the Uvs-Nuur-Basin, Petermann. Geogr. Mitt., 147, 16-23, 2003 (in German).

Pâques, L. E.: Relationship between foliar nutrient concentrations and growth of hybrid larch (Larix $\times$ eurolepsis Henry), Forest Ecol. Manag., 63, 153-167, https://doi.org/10.1016/03781127(94)90108-2, 1994.

Park, Y. D., Lee, D. K., Stanturf, J. A., Woo, S. Y., and Zoyo, D.: Ecological Indicators of Forest Degradation after Forest Fire and Clear-cutting in the Siberian Larch (Larix sibirica) Stand of Mongolia, J. Korean Forest Soc., 98, 609-617, 2009.

Phu, T. D.: Nutrient requirements of planted European larch in Quebec, Plant Soil, 42, 109-117, https://doi.org/10.1007/BF02186977, 1975.

R Core Team: R: A language and environment for statistical computing, R Foundation for Statistical, Vienna, 2014.

Sankey, T. T., Montagne, C., Graumlich, L., Lawrence, R., and Nielsen, J.: Lower forest-grassland ecotones and 20th Century livestock herbivory effects in northern Mongolia, Forest Ecol. Manag., 233, 36-44, https://doi.org/10.1016/j.foreco.2006.05.070, 2006.

Schlütz, F., Dulamsuren, C., Wieckowska, M., Mühlenberg, M., and Hauck, M.: Late Holocene vegetation history suggests natural origin of steppes in the northern Mongolian mountain taiga, Palaeogeogr. Palaeocl., 261, 203-217, https://doi.org/10.1016/j.palaeo.2007.12.012, 2008.

Schulze, E.-D., Schulze, W., Koch, H., Arneth, A., Bauer, G., Kelliher, F. M., Hollinger, D. Y., Vygodskaya, N. N., Kusnetsova, W. A., Sogatchev, A., Ziegler, W., Kobak, K. I., and Issajev, A.: Aboveground biomass and nitrogen nutrition in a chronosequence of pristine Dahurian Larix stands in eastern Siberia, Can. J. Plant Sci., 25, 943-960, https://doi.org/10.1139/x95-103, 1995.

Sharkhuu, N. and Sharkhuu, A.: Effects of Climate Warming and Vegetation Cover on Permafrost of Mongolia, in: Eurasian Steppes, Ecological Problems and Livelihoods in a Changing World, edited by: Werger, M. J. and van Staalduinen, M. A., Springer Netherlands, Dordrecht, 445-472, https://doi.org/10.1007/978-94-007-3886-7_17, 2012. 
Sommer, M.: Die Lärchenwälder der Gebirgs-Waldsteppe im Nordwesten der Mongolei: Ökologische Bestandsaufnahmen und Synthese, Dissertation, 2000 (in German).

Stüber, V.: Untersuchungen zum standortbezogenen Jugendwachstum der europäischen Lärche (Larix europaea, Dc; Larix decidua L.), Zugl.: Göttingen, Univ., Diss., 1998, Cuvillier, Göttingen, 147 pp., 1998 (in German).

Sugimoto, A., Yanagisawa, N., Naito, D., Fujita, N., and Maximov, T. C.: Importance of permafrost as a source of water for plants in east Siberian taiga, Ecol. Res., 17, 493-593, 2002.

Sympilova, D. P. and Gyninova, A. B.: Soils of the subtaiga landscapes on the northern spurs of the Tsagan-Daban Ridge in the Selenga Mountains, Eurasian Soil Sci., 45, 231-236, https://doi.org/10.1134/S1064229312030118, 2012.

Timoshok, E. N. and Skorokhodov, S. N.: Ecology of Siberian Stone Pine (Pinus sibirica Du Tour) and Siberian Larch (Larix sibirica Ledeb.) in the Altai Mountain Glacial Basins, Russ. J. Ecol., 45, 194-200, https://doi.org/10.1134/S1067413614030138, 2014.

Tsogtbaatar, J.: Deforestation and Reforestation of Degraded Forestland in Mongolia, in: The Mongolian Ecosystem Network: Environmental Issues Under Climate and Social Changes, edited by: Yamamura, N., Fujita, N., and Maekawa, A., Springer Japan, Imprint, Springer, Tokyo, 83-98, 2013.

USDA: Soil Survey Field and Laboratory Methods Manual: oil Survey Investigations Report No. 51, Version 2.0. R., 2014.
Viers, J., Prokushkin, A. S., Pokrovsky, O. S., Auda, Y., Kirdyanov, A. V., Beaulieu, E., Zouiten, C., Oliva, P., and Dupré, B.: Seasonal and spatial variability of elemental concentrations in boreal forest larch foliage of Central Siberia on continuous permafrost, Biogeochemistry, 113, 435-449, https://doi.org/10.1007/s10533012-9770-8, 2013.

Wang, H.-M., Wang, W.-J., Chen, H., Zhang, Z., Mao, Z., and $\mathrm{Zu}$, Y.-G.: Temporal changes of soil physic-chemical properties at different soil depths during larch afforestation by multivariate analysis of covariance, Ecol. Evolut., 4, 1039-1048, https://doi.org/10.1002/ece3.947, 2014.

Watanabe, M., Ryu, K., Kita, K., Takagi, K., and Koike, T.: Effect of nitrogen load on growth and photosynthesis of seedlings of the hybrid larch F1 (Larix gmelinii var. japonica $\times$ L. kaempferi) grown on serpentine soil, Environ. Exp. Bot., 83, 73-81, https://doi.org/10.1016/j.envexpbot.2012.04.011, 2012.

Wickham, H.: ggplot2: Elegant graphics for data analysis, Use R!, Springer, Cham, 260 pp., 2016.

Zhang, N., Yasunari, T., and Ohta, T.: Dynamics of the larch taigapermafrost coupled system in Siberia under climate change, Environ. Res. Lett., 6, 24003, https://doi.org/10.1088/17489326/6/2/024003, 2011. 